\title{
Surveys of Significant Plant Resources and Related Vegetation Types for the Butte Office of the Bureau of Land Management
}

\author{
Prepared for:
}

Bureau of Land Management

Butte Field Office

$$
\text { By: }
$$

Scott Mincemoyer

Montana Natural Heritage Program

Natural Resource Information System

Montana State Library

November 2005

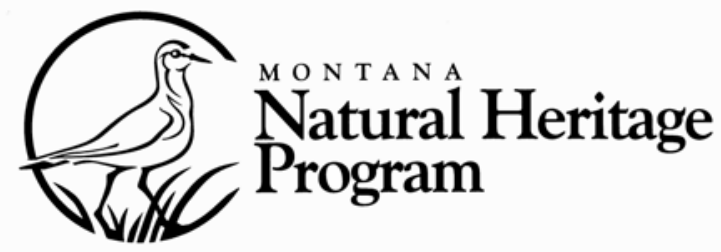





\section{Surveys of Significant Plant Resources and Related Vegetation Types for the Butte Office of the Bureau of Land Management}

Prepared for:

Bureau of Land Management

Butte Field Office

Agreement Number:

ESA010009 - \#21

By:

Scott Mincemoyer
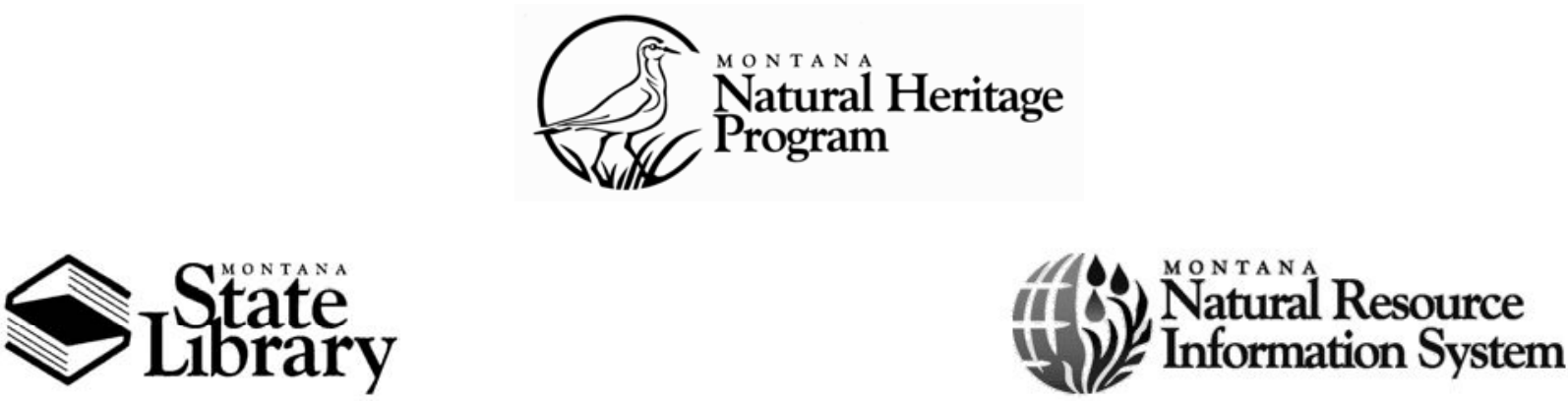

(C) 2005 Montana Natural Heritage Program

P.O. Box $201800 \bullet 1515$ East Sixth Avenue • Helena, MT 59620-1800 • 406-444-5354 
This document should be cited as follows:

Mincemoyer, S. 2005. Surveys of Significant Plant Resources and Related Vegetation Types for the Butte Office of the Bureau of Land Management. Report to the USDI Bureau of Land Management, Butte Field Office. Montana Natural Heritage Program, Helena, MT. 11 pp. + appendices. 


\section{EXECUTIVE SUMMARY}

Lands administered by the Bureau of Land Management (BLM) cover vast and diverse areas of Montana. As such, BLM lands provide significant habitat to many species of conservation concern within the state. The Butte Field Office is no different and accordingly harbors significant populations of several vascular plant Species of Concern (SOC). Lands managed by the Butte Field Office are scattered across areas of southwestern and central Montana. BLM lands in this area are generally small, isolated parcels, though several large, contiguous blocks of BLM land do occur. Total acres managed by the Butte Field Office are approximately 287,000 acres.

The purpose of this report is to document the results of recent surveys for Species of Concern on Butte Field Office lands along with available information on these species' biology, ecology, habitat requirements, etc. Field surveys were conducted by Heritage Program Botany and Ecology staff in 2003-2005. Additionally, data pertaining to all occurrences of known Plant Species of Concern on Field Office administered lands are presented.

Plant Species of Concern in Montana include all S1 and S2 taxa along with G3 (Globally vulnerable) taxa. Many of these species are also ranked as "Sensitive" on BLM lands in the state (Bureau of Land Management 2005). See
Appendix A for a full description of global and state rank definitions.

The field surveys conducted during this project help to provide a clearer picture of the abundance and distribution of these species not only on Butte Field Office lands but across the region. Positive survey results as well as negative (not finding a species in a particular location) survey results both provide valuable information that will be useful for conservation planning and management across BLM lands and other ownerships in the state.

Field surveys conducted as part of this study in 2003-2005 documented four new occurrences of Plant Species of Concern, one Astragalus convallarius, two Brickellia oblongifolia and one Physaria saximontana var. dentata occurrence. The discovery of the Brickellia oblongifolia occurrence along Soap Gulch is only the third known extant location in the state, all three occurring on the Butte Field Office. In addition to the discovery of new occurrences, several other SOC occurrences that were revisited resulted in the expansion of the population, discovery of new subpopulations nearby, current population counts/estimates or in the refinement of mapped population boundaries. In total, 33 occurrences of ten vascular Plant Species of Concern are known on the Butte Field Office. 


\section{ACKNOWLEDGEMENTS}

Data collected in the course of field surveys by Curtis Bjork and Steve Cooper provided the basis for much of the new survey data in this report. Other data collected by numerous individuals, most notably Bonnie Heidel, Peter Lesica and Jim Vanderhorst provide the basis for many of the known occurrences of Species of Concern in this report. Floyd Thompson at the Butte Field Office was instrumental in implementing many aspects of this project and also provided several new occurrences of Astragalus convallarius in the Helena area. As always, thanks to Kathy Lloyd and Coburn Currier for editing and final printing, though any omissions or errors are of my own doing. 


\section{TABLE OF CONTENTS}

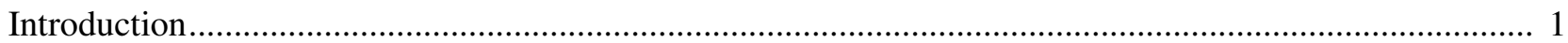

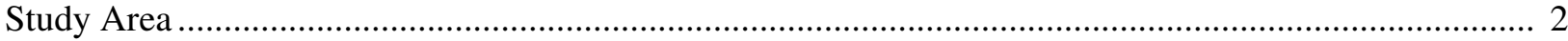

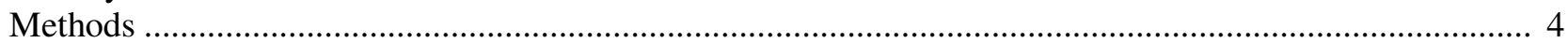

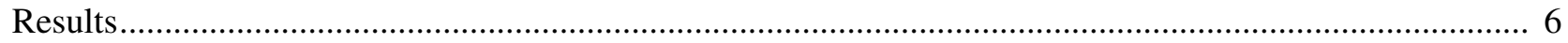

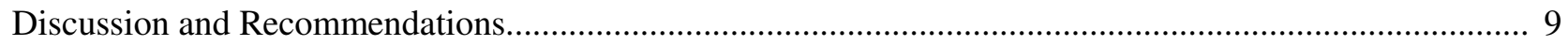

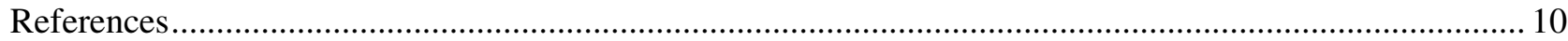

Appendix A. Global/State Rank Definitions

Appendix B. Element Occurrence Rank Definitions

Appendix C. Species Accounts for Plant Species of Concern on the Butte Field Office

Appendix D. Butte Field Office Element Occurrence Maps

\section{LIST OF FigURES}

Figure 1. Butte BLM Field Office with locations of Montana Natural Heritage Program Species of Concern.

\section{LIST OF TABLES}

Table 1. List of Species of Concern originally targeted for survey. …............................................... 4

Table 2. Target sample areas identified prior to fieldwork .......................................................... 5

Table 3. Areas of BLM land surveyed during this study with major findings..................................... 7

Table 4. Documented occurrences of MTNHP Species of Concern (including G3 taxa) on Butte BLM

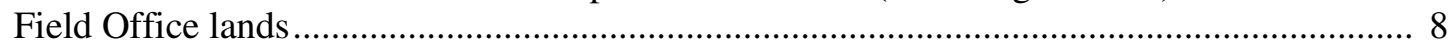





\section{INTRODUCTION}

Lands administered by the Bureau of Land Management (BLM) cover vast and diverse areas of Montana. As such, BLM lands provide significant habitat to many species of conservation concern within the state. The Butte Field Office is no different and accordingly harbors significant populations of several vascular plant Species of Concern.

Plant Species of Concern in Montana include all S1 and S2 taxa along with G3 (globally vulnerable) taxa. Many of these species are also ranked as "Sensitive" on BLM lands in the state (Bureau of Land Management 2005). See Appendix A for a full description of global and state rank definitions.

Several surveys and reports documenting vascular plants on BLM administered lands within the Butte Field Office over the years are available. These surveys and reports include the Limestone Hills area (Heidel 1994; Scow and Culwell 1993; and Scow and Beaver 1999), the Scrtachgravel Hills (Heidel and Cooper 1998), the Doherty Mountain area (Vanderhorst 1994), the Humbug Spires (Lowry II 1919) and a report on threatened, endangered, rare, or sensitive plants of the Headwaters Resource Area on the Butte District of the BLM (Horn 1980).
The purpose of this report is to document the results of recent surveys for Species of Concern on Butte Field Office lands and provide available information on these species' biology, ecology, habitat requirements, etc. Additionally, data pertaining to all known occurrences of plant Species of Concern on Buute Field Office administered lands are presented. However, a great deal of information pertaining to the ecology, distribution, abundance and management of several of these taxa is still lacking and the collection of much of that information is beyond the scope of this provincial project.

The field surveys conducted during this project help to provide a clearer picture of the abundance and distribution of these species not only on Butte Field Office lands but across the region. Positive survey results as well as negative survey (not finding a species in a particular location) results provide valuable information that will be useful for conservation planning and management decisions across BLM lands and other ownerships in the state. 


\section{Study Area}

Lands managed by the Butte Field Office of the Bureau of Land Management (BLM) cover a large and diverse area of southwestern and central Montana. BLM lands in this area are generally scattered and intermixed with other ownerships, and include many small, isolated parcels, though several large, contiguous blocks of BLM land do occur. Surface acres managed by the Butte Field Office were listed at 287,067 acres in 2003. The majority of these lands occur in an area between Melrose in the southwest, Three Forks in the southeast and Wolf Creek in the north. Counties include Broadwater, Deerlodge, Gallatin, Jefferson, Lewis and Clark, Park and Silver Bow.

The topography is varied across the study area though the majority of BLM lands in the area occupy the valleys and the lower slopes of several mountain ranges, as is common with BLM managed lands elsewhere. Mountainous terrain dominates the landscape. The Big Belts, Boulder, Butte Highlands and Elkhorn ranges are the prevalent high mountains in the areas where BLM lands are concentrated. Other minor named ranges, though less prominent, contain some of the most ecologically significant areas in the Butte Field Office, including the Humbug Spires south of
Butte, the Limestone Hills near Townsend and the Scratchgravel Hills just west of Helena.

Dominant vegetation in the area is sagebrush steppe and wheatgrass-fescue grasslands at low to mid elevations. Ponderosa pine and Douglas-fir dominate forested areas at mid elevations and on cooler slopes. The highest elevations support lodgepole pine, spruce-fir and alpine communities.

The study area, being almost entirely east of the Continental Divide, is primarily influenced by a continental climate regime. The weather patterns in the area are typical of many other semi-arid, mountainous regions. Temperatures are highest and precipitation lowest in the valleys, with precipitation increasing significantly at higher elevations with a corresponding decrease in temperature. In Helena, the average maximum daily temperature in July is $82.7^{\circ} \mathrm{F}$ and the average January minimum is $11.2^{\circ} \mathrm{F}$. Annual precipitation in Helena averages 11.9 inches (Western Regional Climate Center 2005). In comparison, the crests of the higher mountain ranges, such as the Elkhorn Mountains, Boulder Mountains and Butte Highlands receive three to four times as much precipitation, with much of it falling as snow. 
Figure 1. Butte BLM Field Office lands with locations of Montana Natural Heritage Program Species of Concern. Only populations wholly or partially occurring on BLM lands are displayed and only the portion of the Field Office with known occurrences is displayed in the larger map.

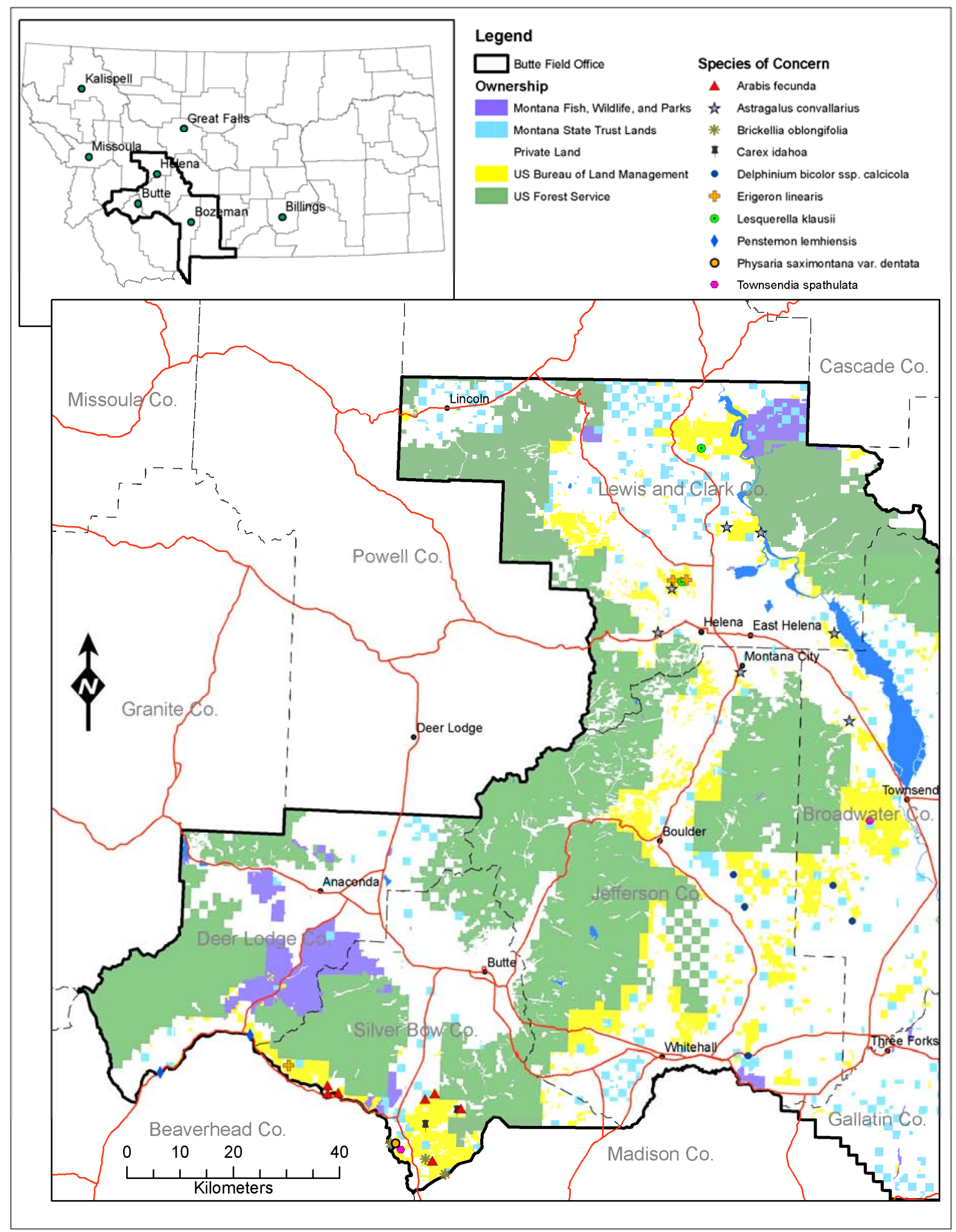




\section{METHODS}

Before the start of the 2003 field season, target vascular plant species and potential sample areas were identified for survey. The primary list of target species and sample areas was identified by Peter Lesica, consulting botanist in Missoula, with additional input by Montana Natural Heritage Program (MTNHP) staff as well as Bureau of Land Management staff. These target species are provided in Table 1 and sample areas are provided in Table 2. Field surveys were conducted by Heritage Program Botany and Ecology staff in 2003-2005.

Surveys were concentrated in areas listed in Table 2 , though several other areas were also surveyed. In addition to the fieldwork component, visits to the University of Montana Herbarium (MONTU) were conducted to document existing occurrences for the Field Office and to collect specimen locations for many of the target species. Existing element occurrences in the MTNHP database were also checked for accuracy of locational data and spatial representation. This step was important due to a previous upgrade in database software that allows for digitally mapping polygonal features in contrast to the old software which only allowed for tracking occurrences as individual points. Specimen collections housed at MONTU and information (e.g. floras, field survey records) housed at MTNHP were also searched for occurrences of Species of Concern on Butte Field Office lands that were never added to the MTNHP database. All survey data collected during this project were entered into MTNHP databases.

Conditions in 2003 were dry and thus not optimal for conducting some of the surveys. Drought conditions during that year undoubtedly made it more difficult to detect plant populations because growth and flowering were reduced for many species. Both 2004 and 2005 were good precipitation years. Field surveys in 2003 were conducted by Curtis Bjork, 2004 surveys by Scott Mincemoyer and additional surveys in 2005 by Steve Cooper.

Table 1. List of Species of Concern originally targeted for survey.

\begin{tabular}{|c|c|c|}
\hline Scientific Name & Common Name & Heritage Rank \\
\hline Adoxa moschatellina & Musk-root & $\mathrm{G} 5 / \mathrm{S} 2$ \\
\hline Allium parvum & Small onion & $\mathrm{G} 5 / \mathrm{S} 2$ \\
\hline Arabis fecunda & Sapphire rockcress & $\mathrm{G} 2 / \mathrm{S} 2$ \\
\hline Astragalus convallarius & Lesser rushy milkvetch & $\mathrm{G} 5 / \mathrm{S} 2$ \\
\hline Carex idahoa & Idaho sedge & $\mathrm{G} 2 / \mathrm{S} 2$ \\
\hline Castilleja gracillima & Slender Indian paintbrush & $\mathrm{G} 3 \mathrm{G} 4 \mathrm{Q} / \mathrm{S} 2$ \\
\hline Erigeron asperugineus & Idaho fleabane & $\mathrm{G} 4 / \mathrm{S} 1$ \\
\hline Erigeron parryi & Parry's fleabane & $\mathrm{G} 2 / \mathrm{S} 2$ \\
\hline Eriogonum soliceps & Railroad canyon buckwheat & $\mathrm{G} 2 / \mathrm{S} 2$ \\
\hline Gentianopsis simplex & Hiker's gentian & $\mathrm{G} 5 / \mathrm{S} 1$ \\
\hline Lesquerella paysonii & Payson bladderpod & $\mathrm{G} 3 / \mathrm{S} 1$ \\
\hline Lesquerella pulchella & Beautiful bladderpod & $\mathrm{G} 2 / \mathrm{S} 2$ \\
\hline Phacelia scopulina & Dwarf phacelia & $\mathrm{G} 4 / \mathrm{SH}$ \\
\hline
\end{tabular}


Table 2. Target sample areas identified prior to fieldwork.

\begin{tabular}{|c|c|c|}
\hline County & Sample Area & Potential Species/Description \\
\hline Broadwater & Johnny Gulch & Adoxa moschatellina and Astragalus convallarius \\
\hline \multirow{3}{*}{ Jefferson } & Doherty Mtn. & Limestone derived soils \\
\hline & $\begin{array}{l}\text { Horse Gulch - Hunting } \\
\text { Gulch }\end{array}$ & Adoxa moschatellina and Astragalus convallarius \\
\hline & $\begin{array}{c}\text { Sheep Rock - St. Paul } \\
\text { Gulch (Golden Sunlight } \\
\text { Mine area) } \\
\end{array}$ & Unusual soil contact zones \\
\hline \multirow{4}{*}{ Lewis \& Clark } & $\begin{array}{c}\text { Beartooth Mtn (Sleeping } \\
\text { Giant) }\end{array}$ & Astragalus convallarius \\
\hline & Hauser Dam area & Astragalus convallarius \\
\hline & $\begin{array}{l}\text { Mahogany Cove - } \\
\text { Crittendon Gulch }\end{array}$ & Astragalus convallarius \\
\hline & Trout Creek area & Astragalus convallarius \\
\hline \multirow{3}{*}{ Silver Bow } & $\begin{array}{l}\text { Moffett Mtn. - Old Glory } \\
\text { Mtn. }\end{array}$ & $\begin{array}{l}\text { Arabis fecunda, Lesquerella pulchella and Phacelia } \\
\text { scopulina; primarily in soils derived from limestone }\end{array}$ \\
\hline & $\begin{array}{l}\text { Moose Creek Wetlands } \\
\quad \text { (Humbug Spires) }\end{array}$ & $\begin{array}{l}\text { Wetland species; e.g. Carex idahoa, Castilleja } \\
\text { gracillima and Gentianopsis simplex }\end{array}$ \\
\hline & North end Humbug Spires & Arabis fecunda \\
\hline
\end{tabular}




\section{RESULTS}

Field surveys conducted as part of this study in 2003-2005 documented four new occurrences of plant Species of Concern (SOC), one Astragalus convallarius, two Brickellia oblongifolia and one Physaria saximontana var. dentata occurrence (Table 4). The discovery of the Brickellia oblongifolia occurrence along Soap Gulch represents only the third known extant location in the state, all three occurring on Butte Field Office land near Melrose. In addition to the discovery of new occurrences, several other SOC occurrences that were revisited resulted in the expansion of the population, discovery of new subpopulations nearby, provided current population counts/estimates or refinement of mapped population boundaries. See Appendix D for mapped locations of all known occurrences of Species of Concern on lands managed by the Butte Field Office.

Several of the target areas identified for survey prior to the start of fieldwork were visited in more than one year (Table 3). However, several areas were only visited once, and for a few of the areas visited in 2003, exact survey dates and locations are uncertain. In addition to the identified target areas, a few other areas were also quickly surveyed (e.g. Kimber Gulch).

Perhaps the most important additions to SOC information and locational data that were added to the MNTHP database during the course of this study are for several globally rare "G3" taxa endemic to Montana that have not been tracked in recent years (see Appendix A for Global/State Ranks). These globally rare, G3 taxa went untracked in recent years for several reasons, perhaps the primary reason being that only $\mathrm{S} 1$ and $\mathrm{S} 2$ ranked plant taxa were previously considered Species of Concern by MTNHP. Additionally, limited financial and personnel resources, as well as limited computer resources, resulted in G3 ranked taxa not being consistently tracked or information updated. Recently, increased attention to globally rare taxa (G1-G3) by federal agencies involved in conservation makes it vital for
MTNHP to include and update information on these species. This effort resulted in eight total occurrences for Delphinium bicolor ssp. calcicola, Lesquerella klausii and Physaria saximontana var. dentata on the Butte Field Office being added to MTNHP databases in the last half of 2005. Addition of the remaining known occurrences and data to MTNHP databases outside of the Butte Field Office for these Montana endemic taxa will occur in the near future.

The only Montana Natural Heritage Program state rank that has changed during the course of this project is the rank for Brickellia oblongifolia. The preliminary state rank for the species after the end of the 2003 field season was S2. After conducting further surveys, the apparent rarity of the species in Montana justifies a change in the state rank to an S1.

In the Doherty Mountain area, Cercocarpus ledifolius (curlleaf mountain mahogany) is abundant on limestone and limestone-derived soils on upper slopes that have a large component of exposed rock and gravel. These extensive communities of curlleaf mountain mahogany are significant because they are some of the most northern occurrences of this vegetation type. Though the species occurs slightly further to the north, the communities in the Doherty Mountain area are worth noting for their extent and adundance near the species' northern limit. Additionally, data were collected on three vegetation communities in the area; these are Pinus flexilis/Cercocarpus ledifolius (limber pine/curlleaf mtn mahogany), Cercocarpus ledifolius/

Pseudoroegneria spicata (curleaf mountain mahogany/bluebunch wheatgrass), and Pascopyrum smithii-Nasella viridula (western wheatgrass-green needlegrass). Though these commuities are not rare in the state they represent, particularly in the case of the western wheatgrass green needlegrass community, examples of each vegetation type on BLM land that are in "good" condition. 
Table 3. Areas of BLM land surveyed during this study with major findings.

\begin{tabular}{|c|c|c|c|}
\hline Survey Sites & Survey Date & $\begin{array}{l}\text { BLM Sections } \\
\text { Surveyed }\end{array}$ & Results \\
\hline $\begin{array}{l}\text { Beartooth Mtn. (Sleeping } \\
\text { Giant) }\end{array}$ & June 23, 2004 & T13N R3W sec 8 & No new occurrences \\
\hline $\begin{array}{c}\text { Brown's Gulch (eastside } \\
\text { Hauser Lake) }\end{array}$ & June 26, 2004 & $\begin{array}{l}\text { T11N, R1W, sec 32, } \\
\text { T10N R1W sec } 6\end{array}$ & No new occurrences \\
\hline Camp Creek & July 1, 2004 & Length of drainage & $\begin{array}{c}2 \text { new subpops for } \\
\text { Brickellia oblongifolia }\end{array}$ \\
\hline $\begin{array}{c}\text { Mahogany Cove - } \\
\text { Crittenden Gulch (Spokane } \\
\text { Hills) }\end{array}$ & June 16, 2004 & T10N, R1W, sec 26, 27 & $\begin{array}{c}\text { New subpops of } \\
\text { Astragalus convallarius }\end{array}$ \\
\hline Doherty Mountain & $\begin{array}{l}\text { June } 22,2004 \text { and } \\
\text { July } 5 \& 12,2005\end{array}$ & T2N, R2W, sec 30,31 & No new occurrences \\
\hline Golden Sunlight Mine & June $21 \& 22,2004$ & $\begin{array}{c}\text { T2N, R3W, sec } 17 \\
\text { T2N, R4W, sec 13, 18, } \\
24\end{array}$ & No new occurrences \\
\hline Hauser Dam & June 9, 2004 & T12N R2W sec 29, 30 & $\begin{array}{c}\text { New occurrence of } \\
\text { Astragalus convallarius }\end{array}$ \\
\hline $\begin{array}{l}\text { Horse Gulch - Dry Creek } \\
\text { (south end of Elkhorns) }\end{array}$ & June 21, 2004 & $\begin{array}{c}\text { T5N, R2W sec } 6 \\
\text { T5N, R3W, sec } 12,14\end{array}$ & No new occurrences \\
\hline $\begin{array}{l}\text { Humbug Spires - north } \\
\text { end }\end{array}$ & $\begin{array}{l}\text { July 9, } 2004 \text { and July } \\
\qquad 8,2005\end{array}$ & $\begin{array}{l}\text { T1N, R8W, sec } 31 \\
\text { T1S, R9W, sec } 1\end{array}$ & $\begin{array}{c}\text { Revisited and better } \\
\text { defined } 2 \text { occurrences of } \\
\text { Arabis fecunda }\end{array}$ \\
\hline $\begin{array}{c}\text { Indian Creek (Limestone } \\
\text { Hills) }\end{array}$ & $\begin{array}{c}\text { July } 2003 \text { and June } \\
17,2004\end{array}$ & $\begin{array}{c}\text { T7N, R1E, sec 25, } 36 \\
\text { T6N, R1W, sec } 1 \\
\text { T6N, R1E, sec 5, } 6 \\
\text { T7NR1E, sec 28, 31, } 32\end{array}$ & No new occurrences \\
\hline $\begin{array}{c}\text { Johnny Gulch (southeast } \\
\text { end of Elkhorns) }\end{array}$ & July 2003 & N.A. & No new occurrences \\
\hline Old Glory Mountain & July 10, 2003 & N.A. & No new occurrences \\
\hline $\begin{array}{l}\text { Moose Creek - MacLean } \\
\text { Creek (Humbug Spires) }\end{array}$ & $\begin{array}{c}\text { July 2003; July } 7 \& \\
8,2004 \text { and July } \\
2005\end{array}$ & $\begin{array}{c}\text { T1S, R9W, sec 12, 13, } \\
\text { 23, 24, } 27 \\
\text { T1S, R8W, sec 7, 10, } \\
18\end{array}$ & $\begin{array}{c}\text { No new occurrences, } \\
\text { revisited } 1 \text { Arabis } \\
\text { fecunda }\end{array}$ \\
\hline Maiden Rock - Goat Mtn. & July 10, 2003 & T1S, R9W, sec 32, 33 & $\begin{array}{c}\text { New occurrence of } \\
\text { Brickellia oblongifolia } \\
\text { and Physaria } \\
\text { saximontana var. dentata }\end{array}$ \\
\hline Pipestone area & June 2004 & N.A. & No new occurrences \\
\hline Soap Gulch & $\begin{array}{l}\text { July 10, 2003; June } \\
30, \text { July } 1 \& 8,2004\end{array}$ & Length of drainage & $\begin{array}{l}1 \text { new occurrence of } \\
\text { Brickellia oblongifolia }\end{array}$ \\
\hline $\begin{array}{c}\text { Trout Creek (eastside of } \\
\text { Hauser Lake) }\end{array}$ & June 26, 2005 & $\begin{array}{l}\text { T11N R2W sec } 18 \\
\text { (north half) }\end{array}$ & No new occurrences \\
\hline Wise River & July 7,2005 & $\begin{array}{l}\text { T1N, R10W sec } 31,32 \\
\text { T1S, R10W, sec } 5\end{array}$ & $\begin{array}{l}\text { Revisit of } 2 \text { Arabis } \\
\text { fecunda occurrences }\end{array}$ \\
\hline Winston - Kimber Gulch & June 17, 2004 & $\begin{array}{l}\text { T8N, R1E, sec 28, 29, } \\
30\end{array}$ & $\begin{array}{c}1 \text { new subpop of } \\
\text { Astragalus convallarius }\end{array}$ \\
\hline
\end{tabular}


Table 4. Documented occurrences of MTNHP Species of Concern (including G3 taxa) on Butte BLM Field Office lands. Populations discovered/surveyed as part of this study are listed in "bold."

\begin{tabular}{|c|c|c|c|c|c|c|}
\hline Taxa & $\begin{array}{c}\text { BLM } \\
\text { Status }\end{array}$ & $\begin{array}{l}\text { Heritage } \\
\text { Rank }\end{array}$ & EO \# & $\begin{array}{c}\text { EO } \\
\text { Rank }\end{array}$ & $\begin{array}{l}\text { Date of First } \\
\text { Survey }\end{array}$ & $\begin{array}{l}\text { Date of Last } \\
\text { Survey }\end{array}$ \\
\hline \multirow{7}{*}{$\begin{array}{c}\text { Arabis fecunda } \\
\text { Sapphire rockcress }\end{array}$} & \multirow{7}{*}{ Sensitive } & \multirow{7}{*}{$\mathrm{G} 2 / \mathrm{S} 2$} & 7 & $\mathrm{~B}$ & June 7,1988 & July 7, 2005 \\
\hline & & & 10 & B & June 7,1988 & June 5, 1990 \\
\hline & & & 16 & A & June 27,1992 & July 8,2005 \\
\hline & & & 17 & A & June 27,1992 & July 9, 2004 \\
\hline & & & 18 & A & June 26, 1992 & July 8, 2005 \\
\hline & & & 21 & $\mathrm{~B}$ & June 11,2002 & June 11,2002 \\
\hline & & & 22 & $\mathrm{~B}$ & July 3, 1994 & July 3, 1994 \\
\hline \multirow{8}{*}{$\begin{array}{l}\text { Astragalus } \\
\text { convallarius } \\
\text { Lesser rushy } \\
\text { milkvetch }\end{array}$} & \multirow{8}{*}{ Sensitive } & \multirow{8}{*}{$\mathrm{G} 5 / \mathrm{S} 2$} & $4^{2}$ & $\mathrm{~B}$ & 1986 & June 17,2004 \\
\hline & & & $8^{2}$ & B & June 11,1980 & June 16, 2004 \\
\hline & & & 9 & $\mathrm{~A}$ & June 20, 1997 & May 26, 2004 \\
\hline & & & 13 & $\mathrm{CD}$ & July 2, 2004 & July 2, 2004 \\
\hline & & & 14 & $\mathrm{CD}$ & July 7,2004 & July 7, 2004 \\
\hline & & & 15 & $\mathrm{C}$ & Sept 26, 2002 & Sept 26, 2002 \\
\hline & & & $16^{1}$ & $\mathrm{BC}$ & June 9, 2004 & June 9, 2004 \\
\hline & & & $\begin{array}{c}\text { Limestone } \\
\text { Hills }^{3}\end{array}$ & $\mathrm{U}$ & N.A. & N.A. \\
\hline \multirow{3}{*}{$\begin{array}{c}\text { Brickellia } \\
\text { oblongifolia } \\
\text { Mohave brickellbush }\end{array}$} & \multirow{3}{*}{--} & \multirow{3}{*}{ G5/S1 } & $\mathbf{1 1}^{1}$ & $\mathrm{~B}$ & July 10, 2003 & July 10, 2003 \\
\hline & & & $2^{1}$ & $\mathrm{CD}$ & July 8,2004 & July 8,2004 \\
\hline & & & $3^{2}$ & $\mathrm{BC}$ & June 20, 2003 & July 1, 2004 \\
\hline $\begin{array}{l}\text { Carex idahoa } \\
\text { Idaho sedge }\end{array}$ & Sensitive & $\mathrm{G} 2 / \mathrm{S} 2$ & 15 & $\mathrm{U}$ & June 11, 1979 & $\begin{array}{l}\text { Failed to } \\
\text { relocate in } \\
2005\end{array}$ \\
\hline \multirow{5}{*}{$\begin{array}{l}\text { Delphinium bicolor } \\
\text { ssp. calcicola } \\
\text { Limestone larkspur }\end{array}$} & \multirow{5}{*}{--} & \multirow{5}{*}{$\begin{array}{l}\text { G4G5T3/ } \\
\text { S3 }\end{array}$} & 1 & $\mathrm{~B}$ & May 28, 1994 & May 28, 1994 \\
\hline & & & 2 & $\mathrm{U}$ & May 28, 1994 & May 28,1994 \\
\hline & & & 3 & $\mathrm{U}$ & May 30, 1994 & May 30, 1994 \\
\hline & & & 4 & $\mathrm{~B}$ & May 30, 1994 & May 30, 1994 \\
\hline & & & 5 & $\mathrm{~B}$ & June 5, 1993 & June 5, 1993 \\
\hline \multirow{3}{*}{$\begin{array}{l}\text { Erigeron linearis } \\
\text { Linear-leaf fleabane }\end{array}$} & \multirow{3}{*}{ Sensitive } & \multirow{3}{*}{ G5/S1 } & 4 & $\mathrm{~B}$ & June 21, 1997 & June 9, 1998 \\
\hline & & & 6 & $\mathrm{~B}$ & June 27, 1999 & June 27,1999 \\
\hline & & & 9 & $\mathrm{~B}$ & June 24, 1997 & June 24, 1997 \\
\hline \multirow{2}{*}{$\begin{array}{l}\text { Lesquerella klausii } \\
\text { Divide bladderpod }\end{array}$} & \multirow{2}{*}{-- } & \multirow{2}{*}{ G3/S3 } & 23 & $\mathrm{C}$ & Sept 13,1987 & Sept 13,1987 \\
\hline & & & 35 & $\mathrm{~B}$ & July 22, 1997 & June 9, 1998 \\
\hline \multirow{2}{*}{$\begin{array}{c}\text { Penstemon } \\
\text { lemhiensis } \\
\text { Lemhi beardtongue }\end{array}$} & \multirow[b]{2}{*}{ Sensitive } & \multirow[b]{2}{*}{$\mathrm{G} 2 / \mathrm{S} 2$} & 49 & A & July 28, 1993 & August 1996 \\
\hline & & & 57 & $\mathrm{D}$ & July 7, 1993 & July 7, 1993 \\
\hline $\begin{array}{c}\text { Physaria } \\
\text { saximontana var. } \\
\text { dentata } \\
\text { Rocky Mtn twinpod }\end{array}$ & -- & G3T3/S3 & 01 & $\mathrm{U}$ & 2003 & 2003 \\
\hline \multirow{2}{*}{$\begin{array}{l}\text { Townsendia } \\
\text { spathulata } \\
\text { Sword townsendia }\end{array}$} & \multirow[b]{2}{*}{--} & \multirow[b]{2}{*}{ G3/S3 } & 6 & $\mathrm{~B}$ & May 21,1985 & May 19, 1993 \\
\hline & & & 10 & U & June 12, 2002 & June 12, 2002 \\
\hline
\end{tabular}

${ }^{1}$ New population discovered as part of this study. ${ }^{2}$ Mapped new subpopulations/expanded occurrence.

${ }^{3}$ Unmapped occurrence based on reported presence of the species in the area by Scow and Beaver 1999. 


\section{DISCUSSION AND RECOMMENDATIONS}

Future surveys on Butte Field Office lands are likely to find additional occurrences of several vascular plant Species of Concern. Occurrences of Erigeron parryi are known from sections adjacent to BLM lands near Doherty Mountain and near the south end of the Elkhorns. However, surveys during this study failed to find any occurrences on BLM lands, with specimens collected in the area being identified as the similar Erigeron ochroleucus. Additional surveys may eventually find $E$. parryi on BLM land in the vicinity. In the Limestone Hills, Polygonum douglasii var. austinae has previously been reported (Scow and Beaver 1999) and Delphinium bicolor ssp. calcicola is suspected (Heidel 1996), though neither were survey targets during this project. Habitat in the area is suitable for both species.

Phacelia scopulina is only known from one historical collection near Melrose. Attempts to relocate this species in the area have been unsuccessful, though future surveys may eventually relocate the species in the vicinity. Surveys in the Melrose area during this project were generally too late in the field season to readily detect this plant.

Surveys of the Moose Creek drainage in the Humbug Spires for several wetland/riparian species (e.g. Carex idahoa, Castilleja gracillima and Gentinopsis simplex) though unsuccessful do not preclude the existence of these or other Species of Concern in the area. Carex idahoa is known from further up the drainage and the riparian area is extensive along sections of Moose Creek in the Humbug Spires and the riparian areas are generally in good condition.
South of the Humbug Spires between Soap Gulch and Camp Creek, the potential for finding Eriogonum soliceps is still good. However, only specimens of the more common and very similar E. mancum were found in this area during field surveys.

Future plant surveys are also likely to find additional occurrences of several of the taxa already known to occur on Butte Field Office lands (Table 4). Specific recommendations for future surveys include the following: Beartooth Mountain (Sleeping Giant) and lands north for Astragalus covallarius, Lesquerella klausii and Erigeron linearis; surveys for the state endemic Delphinium bicolor ssp. calcicola in areas of limestone and limestone-derived soils; additional surveys in the Golden Sunlight Mine area for several taxa in soil contact zones; and additional surveys for Astragalus convallarius in areas of suitable grasslands.

Future revisions of the Montana/Dakotas BLM sensitive plant list should consider the addition of those species listed in Table 4 that are not already listed as "sensitive." Consideration of Delphinium bicolor ssp. calcicola, Lesquerella klausii, Physaria saximontana var. dentata and Townsendia spathulata for addition to the list is warranted due to the global rarity of each, and Brickellia oblongifolia may warrant addition to the list due to its rarity in the state; all three currently known extant occurrences of the species being on BLM lands. 


\section{REFERENCES}

Bjork, C. 2003. Surveys of significant plant resources for the Butte Field Office, BLM, progress report, November 2003. Unpublished report to the Butte Field Office, Bureau of Land Management. Montana Natural Heritage Program, Helena, MT. 4 pp.

Bureau of Land Management. 2005. Montana/Dakotas BLM Sensitive Plant Species List. Montana State Office, Billings, MT. 9 pp.

Dorn, R.D. 1984. Vascular plants of Montana. Mountain West Publishing, Cheyenne, Wyoming. $276 \mathrm{pp}$.

Heidel, B. 1996. Letter to Cliff Youmans. Dated: July 23, 1996.

Heidel, B. 1994. Status review of sword townsendia (Townsendia spathulata) and Limestone Hills survey, Broadwater County, Montana. Unpublished report to the Bureau of Land Management. Montana Natural Heritage Program, Helena, MT. 14 pp. + app.

Heidel, B. L. and S. V. Cooper. 1998. Botanical survey of the Scratchgravel Hills, Lewis and Clark County, Montana. Unpublished report to the Bureau of Land Management. Montana Natural Heritage Program, Helena, MT. 44 pp. + app.

Heidel, B. and J. S. Shelly. 2001. The effects of fire on Lemhi penstemon (Penstemon lemhiensis) final monitoring report, 1995-2000. Montana Natural Heritage Program, Helena, MT. 22 pp. + app.

Heidel, B. and J. S. Shelly. 1997. The effects of fire on Penstemon lemhiensis - monitoring establishment report, 1995 and 1996. Unpublished report to the Beaverhead National Forest and the Bureau of Land Management. Montana Natural Heritage Program, Helena, MT. 11 pp. + app.

Heidel, B. and J. Vanderhorst. 1996. Sensitive plant species surveys: Butte District, Beaverhead and Madison Counties, Montana. Montana Natural Heritage Program, Helena, MT. 85 pp. + app.
Horn, G. 1980. Report on inventory of threatened or endangered, rare, or sensitive plants,

Headwaters Resource Area, Butte District, Montana. U.S. Department of Interior, Bureau of Land Management, Butte, MT. 54 pp.

Lesica, P. 2003. Conserving globally rare plants on lands administered by the Dillon Office of the Bureau of Land Management. Report to the USDI Bureau of Land Management, Dillon Office. Montana Natural Heritage Program, Helena, MT. 22 pp. + appendices.

Lesica, P. 1998. Conservation status of Carex parryana ssp. idahoa in Montana. Montana Natural Heritage Program, Helena, MT. 24 pp. + app.

Lesica, P. 1993. Report on the conservation status of Arabis fecunda, a candidate threatened species. Report to the U.S. Fish and Wildlife Service. Montana Natural Heritage Program, Helena, MT. $52 \mathrm{pp}$.

Lesica, P. and J. S. Shelly. 1995. Effects of reproductive mode on demography and life history in Arabis fecunda (Brassicaceae). American Journal of Botany 82:752-762.

Lesica, P. and J. S. Shelly. 1994. Demography and life history of Arabis fecunda in Ravalli and Beaverhead Counties, Montana. Unpublished report to the Beaverhead National Forest. Montana Natural Heritage Program, Helena, MT. 29 pp.

Lesica, P. and J. S. Shelly. 1992. Effects of cryptogrammic soil crust on the population dynamics of Arabis fecunda (Brassicaceae). American Midl. Nat. 128:53-60.

Lowry II, P. P. 1979. Vascular plants of the Humbug Spires Instant Study Area, Silver Bow County, Montana with a discussion of actually or potentially threatened or endangered species. Butte District, Montana. U.S. Department of Interior, Bureau of Land Management, Butte, MT. 7 pp. + app. 
NatureServe. 2005. NatureServe Explorer: An online encyclopedia of life [web application]. Version 4.5. NatureServe, Arlington, Virginia. Available at: http://www.natureserve.org/explorer.

Scow, K. and J. Beaver. 1999. Vegetation/land condition report for the Limestone Hills property 1998. Unpublished report to the Montana Army National Guard, Helena, MT. WESTECH Environmental Services, Inc., Helena, MT.

Scow, K. L. and L. D. Culwell. 1993.

Supplementary vegetation information for Continental Lime, Inc., Indian Creek Operation, Broadwater County, Montana 1993. Unpublished report to Bison Engineering, Helena, MT. Western Technology \& Engineering, Inc., Helena, MT. 13 pp. + app.

Shelly, J. S. 1990. Report on the conservation status of Penstemon lemhiensis, a candidate threatened species: Montana. Unpublished report to the U.S. Fish and Wildlife Service, Denver. Montana Natural Heritage Program, Helena, MT. $89 \mathrm{pp}$.

Shelly, J. S. 1987. Status review of Penstemon lemhiensis: U.S. Forest Service - Region 1,
Beaverhead and Bitterroot National Forests. Montana Natural Heritage Program, Helena, MT. 29 pp.+ app.

USDA, NRCS. 2005. The PLANTS Database, Version 3.5 http://plants.usda.gov. Data compiled from various sources by Mark W. Skinner.

National Plant Data Center, Baton Rouge, LA 70874-4490 USA.

Vanderhorst, J. 1994. Survey for sensitive plant species on Doherty Mountain, Jefferson County. Unpublished report to the Bureau of Land Management. Montana Natural Heritage Program, Helena, MT. 5 pp. + app.

Vanderhorst, J. and P. Lesica. 1994. Sensitive plant survey in the Tendoy Mountains, Beaverhead County, Montana. Montana Natural Heritage Program, Helena, MT. 59 pp. + app.

Western Regional Climate Center. 2005. Helena WSO, Montana, Period of record climate summary: $1 / 1 / 1893$ to $3 / 31 / 2005$. Reno, NV. Online at: http://www.wrcc.dri.edu/cgibin/cliMAIN.pl?mthele. 



\section{ApPendix A. Global/State RANK Definitions}





\section{HERITAGE PROGRAM RANKS}

The international network of Natural Heritage Programs employs a standardized ranking system to denote global (range-wide) and state status. Species are assigned numeric ranks ranging from 1 to 5, reflecting the relative degree to which they are "at-risk". Rank definitions are given below. A number of factors are considered in assigning ranks - the number, size and distribution of known "occurrences" or populations, population trends (if known), habitat sensitivity, and threat. Factors in a species' life history that make it especially vulnerable are also considered (e.g., dependence on a specific pollinator).

GLOBAL RANK DEFINITIONS (NatureServe 2003)

G1

G2

G3

G4

G5

T1-5
Critically imperiled because of extreme rarity and/or other factors making it highly vulnerable to extinction

Imperiled because of rarity and/or other factors making it vulnerable to extinction Vulnerable because of rarity or restricted range and/or other factors, even though it may be abundant at some of its locations Apparently secure, though it may be quite rare in parts of its range, especially at the periphery

Demonstrably secure, though it may be quite rare in parts of its range, especially at the periphery

Infraspecific Taxon (trinomial) - The status of infraspecific taxa (subspecies or varieties) are indicated by a "T-rank" following the species' global rank

\section{STATE RANK DEFINITIONS}

S1

At high risk because of extremely limited and potentially declining numbers, extent and/or habitat, making it highly vulnerable to extirpation in the state

S2 At risk because of very limited and potentially declining numbers, extent and/or habitat, making it vulnerable to extirpation in the state

S3 Potentially at risk because of limited and potentially declining numbers, extent and/or habitat, even though it may be abundant in some areas

S4 Uncommon but not rare (although it may be rare in parts of its range), and usually widespread. Apparently not vulnerable in most of its range, but possibly cause for long-term concern

S5 Common, widespread, and abundant (although it may be rare in parts of its range). Not vulnerable in most of its range

\section{COMBINATION RANKS}

G\#G\# or S\#S\# Range Rank-A numeric range rank (e.g., G2G3) used to indicate uncertainty about the exact status of a taxon

\section{QUALIFIERS}

NR Not ranked

Q Questionable taxonomy that may reduce conservation priority-

Distinctiveness of this entity as a taxon at the current level is questionable; resolution of this uncertainty may result in change from a species to a subspecies or hybrid, or inclusion of this taxon in another taxon, with the resulting taxon having a lower-priority (numerically higher) conservation status rank 
$\mathrm{X}$

$\mathrm{H}$

$\mathrm{U}$

HYB

$?$

$\mathrm{C}$

A

Z

$\mathrm{P}$

$\mathrm{R}$

SYN

$*$

B

$\mathrm{N}$

Presumed Extinct-Species believed to be extinct throughout its range. Not located despite intensive searches of historical sites and other appropriate habitat, and virtually no likelihood that it will be rediscovered

Possibly Extinct - Species known from only historical occurrences, but may never-theless still be extant; further searching needed

Unrankable - Species currently unrankable due to lack of information or due to substantially conflicting information about status or trends

Hybrid-Entity not ranked because it represents an interspecific hybrid and not a species

Inexact Numeric Rank-Denotes inexact numeric rank

Captive or Cultivated Only-Species at present is extant only in captivity or cultivation, or as a reintroduced population not yet established

Accidental-Species is accidental or casual in Montana, in other words, infrequent and outside usual range. Includes species (usually birds or butterflies) recorded once or only a few times at a location. A few of these species may have bred on the one or two occasions they were recorded

Zero Occurrences-Species is present but lacking practical conservation concern in Montana because there are no definable occurrences, although the taxon is native and appears regularly in Montana

Potential-Potential that species occurs in Montana but no extant or historic occurrences are accepted

Reported-Species reported in Montana but without a basis for either accepting or rejecting the report, or the report not yet reviewed locally. Some of these are very recent discoveries for which the program has not yet received first-hand information; others are old, obscure reports

Synonym-Species reported as occurring in Montana, but the Montana Natural Heritage Program does not recognize the taxon; therefore the species is not assigned a rank

A rank has been assigned and is under review. Contact the Montana Natural Heritage Program for assigned rank

Breeding-Rank refers to the breeding population of the species in Montana Nonbreeding-Rank refers to the non-breeding population of the species in Montana 


\section{APPENDIX B. ELEMENT OCCURRENCE RANK DEFINITIONS}





\section{ELEMENT OCCURRENCE RANK DEFINITIONS}

A - Excellent estimated viability/ecological integrity

A? - Possibly excellent estimated viability/ecological integrity

$\mathrm{AB}$ - Excellent or good estimated viability/ecological integrity

AC - Excellent, good, or fair estimated viability/ecological integrity

B - Good estimated viability/ecological integrity

B? - Possibly good estimated viability/ecological integrity

BC - Good or fair estimated viability/ecological integrity

BD - Good, fair, or poor estimated viability/ecological integrity

C - Fair estimated viability/ecological integrity

C? - Possibly fair estimated viability/ecological integrity

CD - Fair or poor estimated viability/ecological integrity

D - Poor estimated viability/ecological integrity

D? - Possibly poor estimated viability/ecological integrity

E - Verified extant (viability/ecological integrity not assessed)

F - Failed to find

F? - Possibly failed to find

$\mathrm{H}$ - Historical

H? - Possibly historical

$X$ - Extirpated

$\mathrm{X}$ ? - Possibly extirpated

U - Unrankable

NR - Not ranked 



\section{APPENDix C. SPECIES ACCOUNTS FOR Plant SPECIES OF CONCERN ON THE BUTTE FIELD OFFICE}



Arabis fecunda (Brassicaceae)

Sapphire rockcress

BLM Status: Sensitive

Heritage Ranking: G2/S2

RANK JUSTIFICATION: Sapphire rockcress is a state endemic known from several locations in three mountain ranges where it is restricted to specific and localized habitats. Encroachment of spotted knapweed threatens several populations that may be genetically distinct. It is unclear whether grazing has significant negative impacts.

IDENTIFICATION: Arabis fecunda is a small perennial with 1 to many clusters of basal leaves arising from a simple or branched rootcrown and

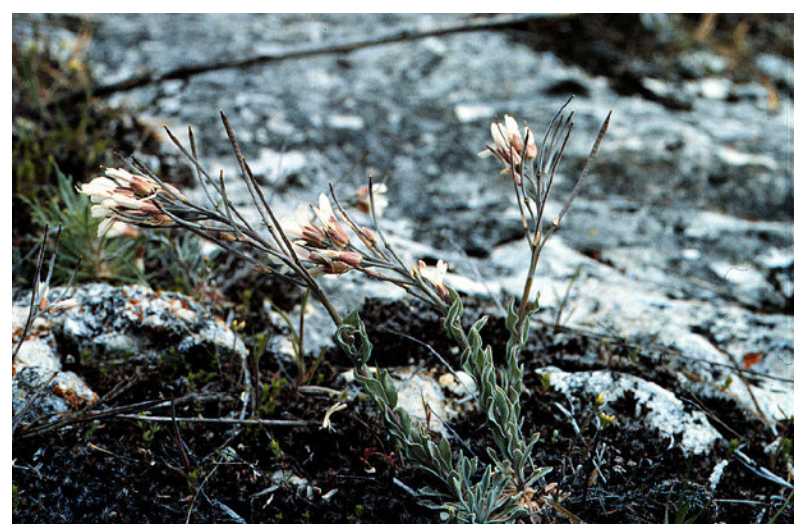

Arabis fecunda plant

1 to many, unbranched, flowering stems that are up to $30 \mathrm{~cm}$ high. The spoon-shaped or lance-shaped basal leaves are 10-30 mm long and 2-4 $\mathrm{mm}$ wide, with entire margins or a few shallow lobes toward the tip; the stem leaves are smaller and clasping. Usually two distinct types of basal leaves can be distinguished: larger, broader ones produced in the fall, and narrower ones produced in the spring. The leaves and stem are grayish-white with a dense cover of small, branched hairs. The several to many white or blush-tinged flowers are borne in an unbranched spike-like inflorescence. Flowers are tightly clustered at first, but become further apart in fruit; they have 4 petals, which are 9-13 mm long and 3-5 mm wide, and densely hairy sepals, which are 6-7 $\mathrm{mm}$ long and about $2 \mathrm{~mm}$ wide. The grayish, hairy fruits are 3-5 $\mathrm{cm}$ long and 1-2 mm wide; they are held nearly erect when mature and have two narrow chambers with a single row of small seeds in each one. Flowering occurs from late April-early June.

The relatively small size and densely hairy, erect fruits of Arabis fecunda are distinctive. Arabis hirsuta and A. glabra have erect fruits, but are taller and have larger leaves. Arabis drummondii, A. divaricarpa and $A$. lyallii also have erect fruits, but these are glabrous rather than densely hairy.

HABITAT: Sapphire rockcress is endemic to the northern Rocky Mountains of southwest Montana. It reaches its northern extent in the western foothills of the Sapphire Range in the Willow Creek drainage (Ravalli County) and extends south to the northern foothills and mountains of the East Pioneer Range (Beaverhead County, lower Big Hole River drainage) and the Highland Mountains (Silver Bow County).

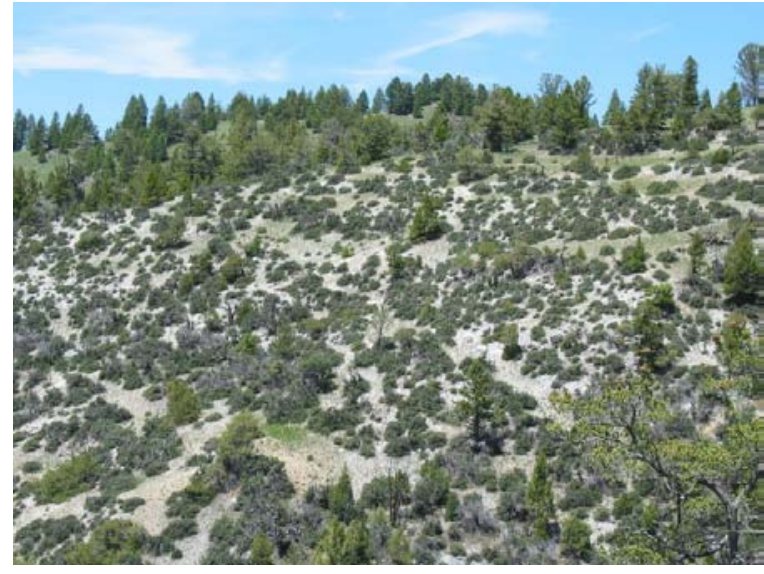

Arabis fecunda habitat (EO \#17)
The species occurs on moderate to steep slopes with warm (SE, S, SW, W) aspects and relatively sparse vegetation. Most sites are in lower slope positions, although populations do occur on mid and upper slopes. Sites in the Sapphire Mountains are at or below 5000 feet while populations in the southern portion of the range are 5500-8000 feet. Sapphire rockcress occurs on soils derived exclusively from calcareous sediments that have been metamorphosed to some extent by contact with granitic intrusions (Lesica 1993). Soils are generally sandy in texture with low organic matter content and a light albedo. Soil analyses from the Charley's Gulch site in Ravalli County indicate a silty-sand texture and high 
calcium content. Parent materials from Ravalli County belong to the Wallace Formation in the Precambrian Belt Series, while those from Beaverhead and Silver Bow Counties are Paleozoic Madison limestone.

In Ravalli County, zonal vegetation is typically Artemisia tridentata/Festuca idahoensis/Elymus spicatus steppe, sometimes with a sparse overstory of Pinus ponderosa. In Beaverhead and Silver Bow Counties, it grows in Cercocarpus ledifolius, Juniperus scopulorum or Pinus flexilis woodland, very open Pseudotsuga menziesii forest, or sparse Elymus spicatus grassland.

ECOLOGY: Sapphire rockcress occurs in areas of relatively sparse vegetation. At three sites in Ravalli and Beaverhead Counties, coverage of bare soil varied from 40-80\%, and basal vegetation from 20-50\% (Lesica and Shelly 1994). Many of the sites occur on steep slopes with periodic natural erosion. In some cases these slopes support cryptogamic soil crusts that are beneficial to the survival of older, larger individuals of the species (Lesica and Shelly 1992). Periodic erosion and slumping of steep slope habitat may be partially responsible for maintaining sparse vegetation with reduced competition for light, water and nutrients (Lesica 1993). Many sites would be considered early successional or edaphic disclimaxes, and these conditions may be important for the species' persistence. Fire was relatively frequent in many of these areas, but the sparse vegetation on the slopes occupied by this species probably did not carry fire well.

MANAGEMENT CONSIDERATIONS: Several factors may affect the long-term persistence of this species, including exotic weed encroachment, grazing, herbicide application, mining and pathogens. Spotted knapweed (Centaurea maculosa) has severely invaded Arabis fecunda habitat in Ravalli County, and studies have shown reduced recruitment of new Sapphire rockcress plants into the population in these areas. Spotted knapweed is an aggressive Eurasian weed present at all sites in Ravalli County. This taprooted perennial is widely introduced in North America where it has become a serious invader of semiarid grasslands in the Pacific Northwest and intermountain valleys of the northern Rocky Mountains. Its ability to invade and replace native plants is well documented. Most of our Arabis fecunda sites have severe infestations of spotted knapweed. It has been shown to have adverse effects on many native species including sapphire rockcress. Research on water-use efficiency in this species has shown significant differences between low-elevation populations in the Bitterroot Valley and those at higher sites in Beaverhead County, suggesting that Bitterroot Valley populations, which are most threatened by weed encroachment, may be genetically distinct.

Roads are a major source of weed infestation, and road construction or other major disturbances that may introduce or provide avenues for the introduction of weeds could negatively impact populations of sapphire rockcress. Livestock can also be a significant vector for exotic weed encroachment. Currently, spotted knapweed does not occur at the Beaverhead or Silver Bow County sites, but it does occur in these counties and may become a problem.

Livestock grazing occurs at most sites, although heavy grazing is reported for fewer than half of the sites. Direct herbivory has never been observed and is probably rare, however, soil crusts are beneficial to the species' survivorship at some sites; such crusts are often destroyed by livestock. Livestock can also adversely affect survivorship by trampling plants. Exclosure studies were conducted at two sites near the Big Hole River. At one site sapphire rockcress increased in the grazing exclosure while it decreased in another. Sapphire rockcress establishes best when not competing with other species, and grazing may limit competition. It is interesting to note that some of the largest populations (Birch Creek and Jerry Creek) are in areas with the most intensive grazing.

Herbicide application is currently the most commonly employed method for controlling spotted knapweed infestations, however, little is known about the specific effects on sapphire rockcress, so herbicide 
application should be avoided in direct proximity to sapphire rockcress populations. At this time only one sapphire rockcress site is near an active mine, and it has not been impacted to date. Nonetheless, there are populations near mining claims or inactive mines that could become active with improved extraction methods or increases in the value of minerals [from Lesica 2003]. 
Astragalus convallarius var. convallarius (Fabaceae)

\title{
Lesser rushy milkvetch
}

\author{
BLM Status: Sensitive \\ Heritage Ranking: G5/S2
}

RANK JUSTIFICATION: The distribution of A. convallarius in Montana is limited to two disjuct localities in the state: the Helena Valley vicinity, and an area in extreme southwest Montana in Beaverhead County. The species is being negatively impacted by development in portions of the Helena area, and past development in the Helena Valley probably eliminated areas of previously occupied habitat resulting in the more fragmented distribution seen today. The grassland habitats this species occupies are also being invaded by several noxious weeds. Several large occurrences are presently known and some areas of potentially suitable habitat remain unsurveyed.

IDENTIFICATION: Lesser rushy milkvetch is a slender, herbaceous perennial with 1-6 erect to spreading stems, rising up to $5 \mathrm{dm}$ high from a branching, underground rootcrown. The compound or simple leaves are $2-11 \mathrm{~cm}$ long with $0-5$ pairs of thread-like leaflets. Leaflets of the upper leaves are usually lacking, giving them a grass-like appearance. Foliage is sparsely hairy to glabrous in the upper portion. Off-white or yellowish, pea-like flowers are sparsely scattered on stalks which are 2$14 \mathrm{~cm}$ long and arise from the axils of the upper leaves. The upper petal of each flower is $7-11 \mathrm{~mm}$ long and bent upward. The calyx is 4-6 $\mathrm{mm}$ long and sparsely covered with white or black hairs.

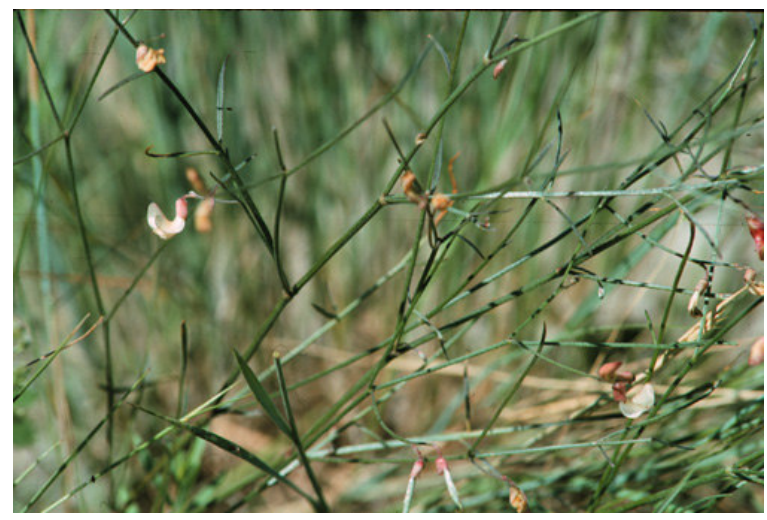

Astragalus convallarius plant

Pendent, green or purple-mottled fruits are bean-shaped, 13-50 mm long, and 2-4 mm wide. Flowering occurs from June-early July, fruiting in late June-early August.

Only the typical variety of the species is known in the state. A. ceramicus looks similar in appearance but can be distinguished by the shorter calyx tube $(2-3.5 \mathrm{~mm}$ long) and the inflated, oblong-ellipsoid pods,

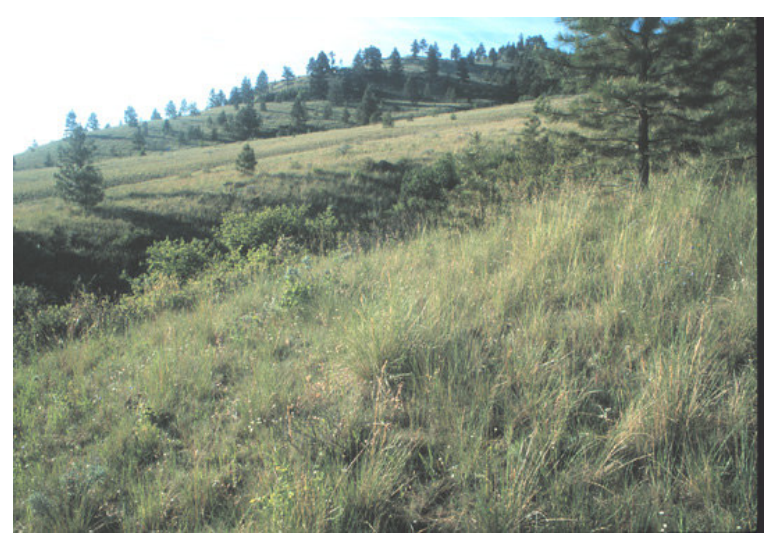

Astragalus convallarius habitat whereas the pods of A. convallarius are compressed and linear to oblong. Astragalus convallarius has sometimes been lumped with the species $A$. diversifolius.

HABITAT: Astragalus convallarius occupies grasslands and open ponderosa pine woodlands in the valleys and foothills. Festuca scabrella, Festuca idahoensis, and Elymus spicatus are common bunchgrass associates. 
Brickellia oblongifolia var. oblongifolia (Asteraceae)

Mohave brickellbush

BLM Status: None

Heritage Ranking: G5/S1

RANK JUSTIFICATION: Only three extant occurrences are known in the state, all occurring near Melrose. The current status of one historical occurrence near Wilsall is unknown.

IDENTIFICATION: Glandular-puberulent herb or subshrub, 1-6 dm tall, generally with many stems from near the base. Leaves all cauline, mostly sessile, alternate or occasionally opposite to subopposite, entire or nearly so, lance-linear to oblong or elliptic, $1-4 \mathrm{~cm}$ long and up to $15 \mathrm{~mm}$ wide. Leaves mostly 2-8 times as long as wide. Heads terminating the branches or subcorymbosely clustered and relatively large. The involucres 10-20 mm high with acute to acuminate bracts. Flowers ochroleucous, numerous with about 40-50 flowers in each head. Achenes 4.5-6 mm long.

Brickellia oblongifolia is similar to Brickellia grandiflora, which differs in having broad, toothed leaves. B. eupatorioides closely resembles B. oblongifolia, but has toothed leaves and feathery (plumose) pappus bristles on the top of the fruit. B. oblongifolia var. oblongifolia is the only variety of the species in Montana.

HABITAT: Typical habitats include rock outcrops, talus, and scree; and dry, sparsely-vegetated, southerly slopes.

Additional information on management considerations for the species, as well as information on the species' ecology in Montana is not available at this time. 
Carex idahoa (Cyperaceae)

(syn: Carex parryana ssp. idahoa)

\section{Idaho sedge}

\section{BLM Status: Sensitive}

Heritage ranking: G2/S2

RANK JUSTIFICATION: Carex idahoa is a regional endemic known from just over 30 sites in Montana, most on public lands. The estimated number of stems reaches tens of thousands, but total occupied habitat is estimated at less than 200 acres. The species is palatable and populations may be affected by heavy grazing. Other risks are competition from exotic species, hydrologic alterations, agricultural development, and road construction/maintenance.

IDENTIFICATION: Idaho sedge forms small clumps that arise from rhizomes. The stems are 20-35 cm high with most leaves crowded near the base. Leaves are flat and 2-4 mm wide. Flowers are clustered in 1-4 oblong-cylindrical spikes, each 1-3 cm long, with the uppermost being larger than the others. Male flowers are absent or scattered among the perigynia on the largest spike. The spikes form a narrow, interrupted head, subtended by small leaf-like bracts, at the top of the stems. The narrowly oval scales subtending each perigynia taper to the tip and are 2-3 times longer than the perigynia. These scales are brown with membranous margins and a distinct pale center. The glabrous, egg-shaped perigynia are yellow-green and about $3 \mathrm{~mm}$ long with a short beak. There are 3 stigmas and the seed is 3-sided. Fruits mature in July-August. The uppermost spikes of Carex parryana ssp. parryana are cylindrical and more-or-less equal

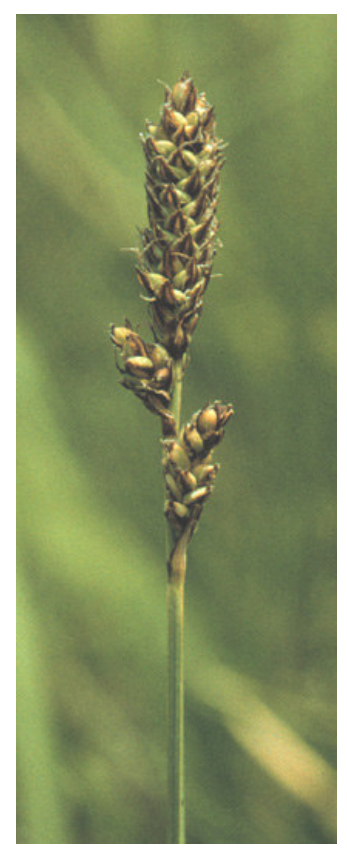

Carex idahoa in size, while in Carex idahoa and Carex parryana ssp. hallii, the terminal spike is enlarged and clubshaped. Female scales of C. p. ssp. hallii are as long as the perigynia, while they are much shorter than the perigynia in $C$. idahoa.

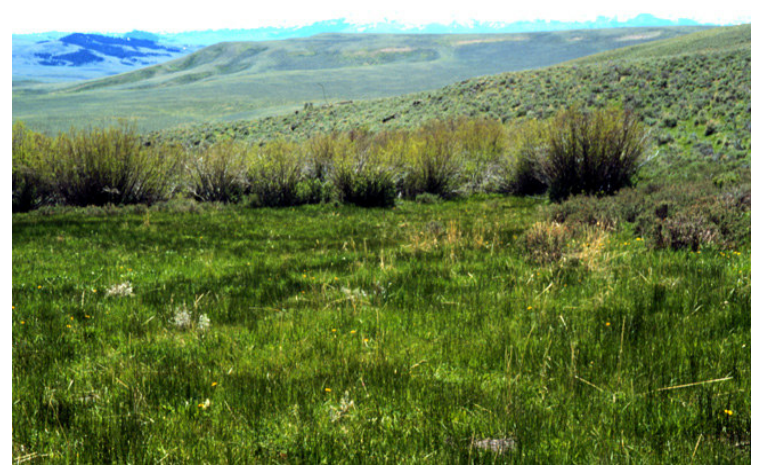

Carex idahoa habitat
HABITAT: Carex idahoa occurs in moist, alkaline meadows, often along streams (Vanderhorst and Lesica 1994). It most often occupies ecotonal areas between wet meadow and sagebrush steppe (Lesica 1998), and appears to be restricted to nearly level sites in the high valleys of southwest Montana. It is commonly found on terraces of headwater streams above 6000 feet elevation. Small populations may occur at lower elevations or along larger streams. Soils tend to be silty, with ample organic matter with little or no coarse material (Lesica 1998). Most documented Montana populations are in areas with calcareous parent material, however a few occupy non-calcareous sites.

Its moist, alkaline, streamside meadow habitat is typically dominated by graminoids (especially Deschampsia caespitosa, Juncus balticus, Carex praegracilis, Carex nebrascensis, C. aquatilis), with or without Potentilla fruticosa (Vanderhorst and Lesica 1994; Lesica 1998). Adjacent steppe vegetation is dominated by Artemisia tridentata and/or A. tripartita, Festuca idahoensis, and Agropyron smithii. Species most commonly associated with Idaho sedge are, in order of importance, Juncus balticus, C. praegracilis, Muhlenbergia richardsonis, Aster occidentalis, Poa pratensis, Taraxacum officinale, Potentilla gracilis, and Antennaria microphylla. Graminoid cover is high (60-100\%), and forb cover low to moderate (5-50\%) except in overgrazed areas. Bare ground averages $8 \%$ and cover of lichens and 
bryophytes averages 14\% (Lesica 1998). Idaho sedge consistently occurs in subirrigated soils associated with low-gradient streams or springs and seeps. These soils are wet early in the growing season but are only moist later in the summer. In wetlands where part of the habitat is saline (as indicated by the presence of Distichlis and Puccinellia), it is usually limited to non-saline areas, although it has been found in salt-encrusted soils (Lesica 1998).

ECOLOGY: Flooding is probably uncommon in most of these habitats, as they tend to occur in headwater areas where snow accumulation and stream gradients are low (Lesica 1998). Although fire was common in high-elevation steppe vegetation in southwest Montana prior to European settlement, it probably did not play an important role in the dynamics of herbaceous riparian wetlands (Lesica 1998).

MANAGEMENT CONSIDERATIONS: Carex idahoa can probably tolerate light to moderate livestock grazing but will decline under heavy grazing (Lesica 1998). Its wetland habitat is favored by cattle and frequently subject to overgrazing on both public and private lands. Graminoids such as sedges are adapted to grazing and are usually able to persist with light to moderate grazing pressure (Lesica 1998). Evidence suggests that this species responds to grazing similarly to many palatable graminoids, and is capable of tolerating light to moderate grazing, but would likely decline under continuous heavy grazing. This is based on correlation data and studies of other, anatomically similar species. Experiments and monitoring studies to determine the actual response of Idaho sedge have not been conducted (Lesica 1998); however grazing regimes that permit $50 \%$ or less annual utilization and allow seed production and dispersal at regular intervals will likely be compatible with its survival.

Almost all known populations of the species on public land are subject to livestock grazing, as is much of its habitat on private land (Lesica 1998). Its mesic habitat provides high quality, green forage for livestock throughout the summer and is a magnet for cattle, often leading to overgrazing. Many of the small populations occur in localized springs, seeps, or along small streams in extensive semi-arid steppe, and are particularly at-risk from overgrazing, which can cause streambank destabilization followed by lowering of the water table and a loss of riparian vegetation (Lesica 1998). Populations in larger wetland areas may not face such intensive grazing pressure.

Large areas of potential habitat for this species in southern Beaverhead County are mowed for hay. While the effects of mowing on native vegetation are unknown, plowing and seeding of non-native species almost certainly have adverse effects on native communities and may result in local extirpation of native species. Poa pratensis (Kentucky bluegrass) is the only exotic plant documented with significant frequency in this species' habitat (Lesica 1998). It is a rhizomatous grass similar in stature to the Idaho sedge, and may compete with it, especially where there is grazing and trampling by livestock. Taraxacum officinale (dandelion) and Trifolium repens (clover) occur at some sites, but these are short plants that increase only where heavy grazing removes the larger graminoids, and by themselves do not pose a threat to Idaho sedge.

Roads are often constructed along or adjacent to riparian areas, and have impacted wetland habitat for three Idaho sedge populations (Lesica 1998). A fourth is vulnerable to road improvement and construction. Road development can reduce or degrade habitat through increased runoff, pollution, and physical disturbance. Use of these roads for ranching and recreation probably has little impact on the species; however maintenance or widening can lead to habitat loss. A portion of Moose Creek, where one population occurs, has been dredged, presumably for mineral extraction (Lesica 1998). Dredging most likely reduces the extent and character of riparian vegetation, and may reduce habitat for Idaho sedge. Fortunately, most populations do not occur in areas prone to mining activity [from Lesica 2003]. 
Delphinium bicolor ssp. calcicola (Ranunculaceae)

\section{Limestone larkspur}

BLM Status: None

Heritage ranking: G4G5T3/S3

RANK JUSTIFICATION: Endemic to Montana.

IDENTIFICATION: Limestone larkspur is a perennial 10-30 $\mathrm{cm}$ tall arising from deep roots branched at least 1 $\mathrm{cm}$ below the stem attachment. Leaves are on the lower $1 / 3$ of the stem, with 2-7 basal leaves at the time of flowering. Leaf blades are 1.5-7 cm long, round in

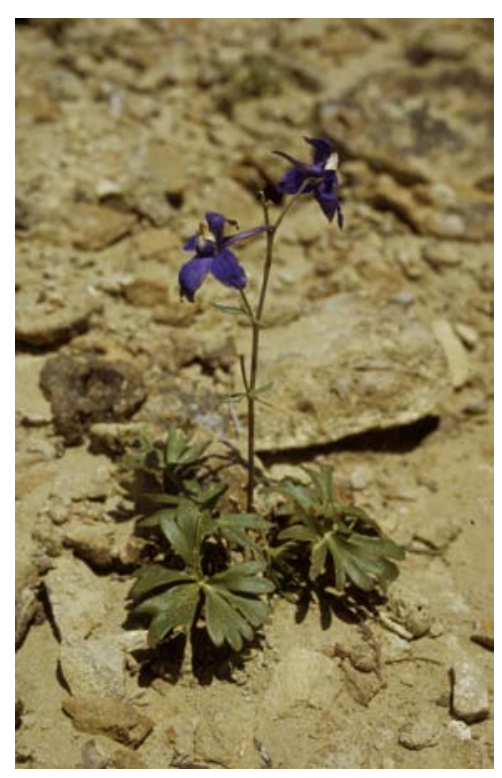
outline, with few-many lobes, and glabrous to puberulent. Sepals are bright, dark blue, $16-21 \mathrm{~mm}$ long, and there is a cleft in the lower petals at least $2 \mathrm{~mm}$ deep. Flowering occurs in late spring to early summer although usually somewhat later than the typical subspecies where the two overlap.

Distinguished from the widespread Delphinium bicolor ssp. bicolor by the bright blue sepals, the deep cleft in lower petal blades $2 \mathrm{~mm}$ or greater, and upper petals with solid white-lavender tips rather than with distinct purple veins. Most collections of this taxon prior to 1995 have typically been identified as $D$. andersonii or D. geyeri.

HABITAT: Common habitats include shortgrass prairie and grasssagebrush communities on limestone-derived soils, usually with coarse fragments at the surface, or on limestone outcrops. Elevations typically range from 4,200-6,800 feet.

Delphinium bicolor ssp. calcicola

Additional information on management considerations for the species, as well as information on the species' ecology in Montana is not available at this time. 


\section{Erigeron linearis (Asteraceae)}

\section{Linear-leaf fleabane}

BLM Status: Sensitive

Heritage ranking: G5/S1

RANK JUSTIFICATION: Erigeron linearis is a peripheral species known from a few small, localized occurrences. Mining, grazing and the encroachment of exotic weeds are factors that may affect long-term population stability.

IDENTIFICATION: Linear-leaf fleabane has unbranched stems that are 5-30 cm tall and which arise from a stout taproot and branched rootcrown. The mostly basal leaves are linear and $1-9 \mathrm{~cm}$ long. The bases of the stems and leaves are enlarged and

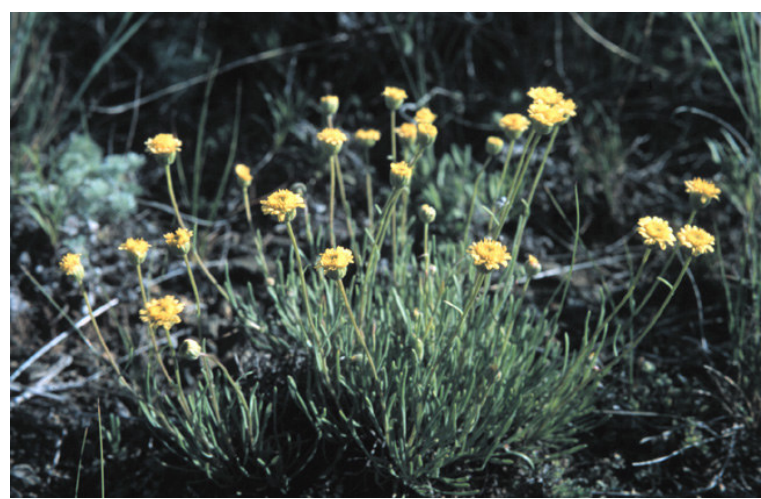

Erigeron linearis straw-colored or purplish, and the herbage is covered with fine, gray hairs. The flower heads are usually solitary at the ends of the stems. The involucral bracts are 4-7 $\mathrm{mm}$ long and are covered with long, appressed hairs and occasionally also with glands. The $15-45$ yellow rays are $4-11 \mathrm{~mm}$ long and the yellow disk flowers are 3-5 mm long. There are 10-20 pappus bristles at the top of each achene. Flowering occurs from May to early June.

Linear-leaf fleabane is our only Erigeron with yellow ray flowers. Erigeron filifolius also has narrowly linear leaves but the ray flowers are white or blue and there is more than one head per stem. Members of the genus Stenotus (formerly Haplopappus) have yellow rays, but the involucral bracts are in 2-3 series of different height.

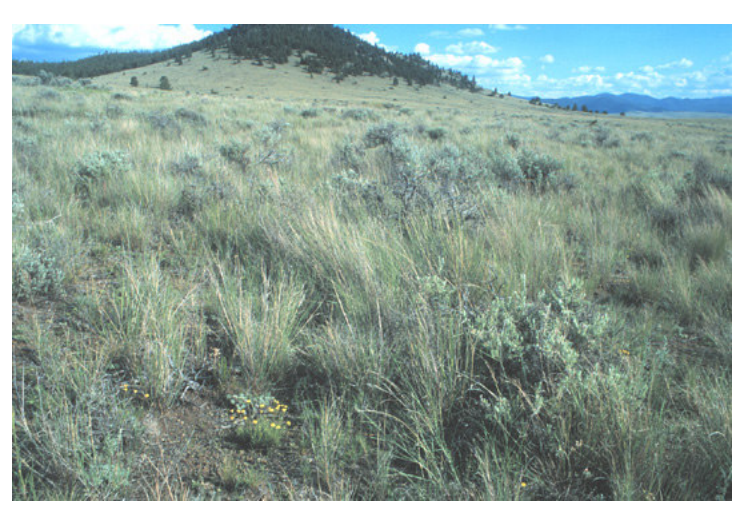

Erigeron linearis habitat
HABITAT: Erigeron linearis occurs in dry, often rocky soil from the foothills up to moderate elevations, frequently with sagebrush (Heidel and Cooper 1998). Dominant species in its habitat include bluebunch wheatgrass (Elymus spicatus) and mountain big sagebrush (Artemisia tridentata ssp. vaseyana). Associated species and habitats vary widely. In the Scratchgravel Hills near Helena, it occupies two distinct habitats - one a midslope opening on a steep east-facing timbered hillside, and the other a gently southwestfacing lower slope in open rolling plains. In Beaverhead County, linear-leaf fleabane was found on granular, diabase-derived soil in rolling sagebrush steppe, where it occupied a disturbed opening dominated by Agropyron

smithii, along with other species characteristic of disturbed areas, including Arenaria kingii, Bromus tectorum, Chrysopsis villosa, Haplopappus acaulis, Oxytropis sericea and Phlox bryoides. Other small populations in Beaverhead and Silver Bow Counties were found in sparse vegetation.

ECOLOGY: Linear-leaf fleabane is an herbaceous perennial. At one locality in Beaverhead County, Heidel and Vanderhorst (1996) speculated that the site may have been grubbed or burned, resulting in removal of the sagebrush cover. The low stature of this plant probably means that it responds positively to the disturbance of livestock grazing. 
MANAGEMENT CONSIDERATIONS: Leafy spurge and spotted knapweed threaten populations in the Scratchgravel Hills. Observations suggest that this species may respond positively to disturbance. Some populations might have been established through human activity, because the species is highly localized within what appears to be extensive suitable habitat, in locations of historically intense mining activity [adapted from Heidel and Cooper 1998]. 
Lesquerella klausii (Brassicaceae)

\section{Divide bladderpod}

BLM Status: None

Heritage ranking: G3/S3

RANK JUSTIFICATION: Lesquerella klausii is a state endemic restricted to central-Montana with the majority of populations occurring in the Big Belt Mountains and extending north to the southern end of the Rocky Mountain Front. Total population numbers are fairly large and the species typically occurs on gravelly slopes that are not usually subject to human disturbance.

IDENTIFICATION: Divide bladderpod is a short-lived perennial forb with a rosette of basal leaves from a taproot and unbranched rootcrown. Flowering stems are 6-15 cm long, erect or lie flattened on the ground and then curving upwards at the tip. Leaves are typically broadly spoon-shaped and 6-9 mm long. Herbage is densely covered with branched, stellate hairs. Flowers are borne on curved or S-shaped pedicels in a loose inflorescence that is $10-30 \mathrm{~mm}$ long. The yellow petals are 6-8 $\mathrm{mm}$ long. The broadly heart-shaped fruits are about 5 $\mathrm{mm}$ wide, $4 \mathrm{~mm}$ tall, compressed perpendicular to the suture, and densely hairy. Flowering occurs in May and early June, fruiting in late May through June.

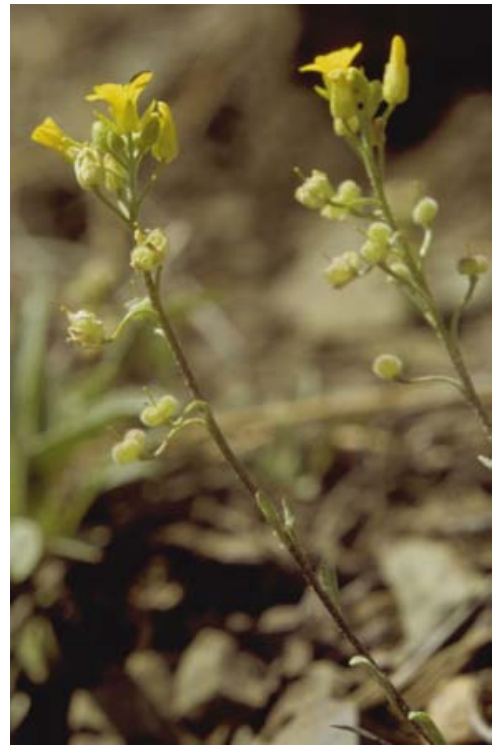

Lesquerella klausii flowers \& fruit

Physaria geyeri closely resembles Lesquerella klausii and a technical manual should be consulted to distinguish between the two. The two species are usually separable by the mostly disjuct ranges of the two; with $P$. geyeri occurring mainly in the southwest part of the state.

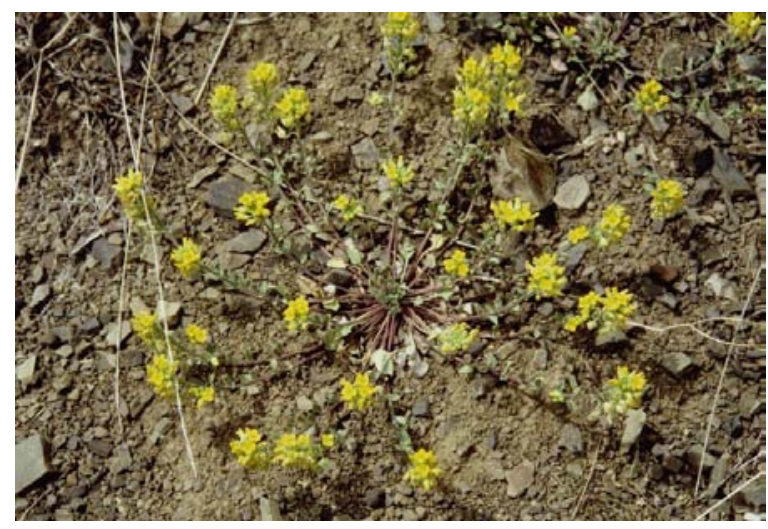

Lesquerella klausii plant
HABITAT: The species occurs on open shale slopes and gravelly areas, at moderate to fairly high elevations in the mountains.

ECOLOGY: Most species of Lesquerella are crosspollinated by insects. Seed dispersal is probably most prevalent near the parent plant, though longer dispersal by wind and gravity are possible. High recruitment levels the two years following a wildfire have been noted. Reproduction by seed is the only means of recruitment. Individual populations vary in size from a few plants to several thousand plants. L. klausii appears tolerant of light to moderate disturbance based on the unstable habitats it frequently occupies. 
Penstemon lemhiensis (Scrophulariaceae)

\section{Lemhi beardtongue}

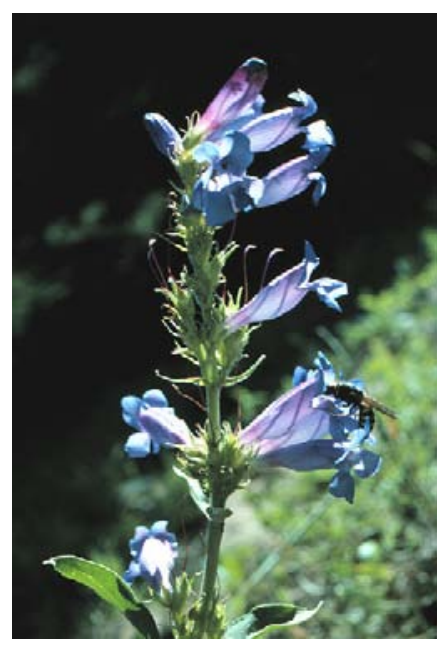

Penstemon lemhiensis
BLM Status: Sensitive

Heritage ranking: G3/S2

RANK JUSTIFICATION: Penstemon lemhiensis is a regional endemic that occurs only in southwest Montana and adjacent Idaho. There are over 50 known populations in Montana, but most have fewer than 100 individuals. Estimates in 1999 placed the total number of individual plants in Montana at about 3000. Its habitat is threatened by the encroachment of spotted knapweed, especially in Ravalli County, and by reduction in wildfire frequency. Mining has also impacted it historically.

IDENTIFICATION: Lemhi beardtongue is a large perennial, with 1 to several stems up to $70 \mathrm{~cm}$ tall arising from a branched rootstock and a short taproot. The leaves are narrowly lance-shaped and entire-margined. The basal leaves have a petiole and are up to $16 \mathrm{~cm}$ long. The opposite stem leaves lack petioles and are reduced upwards. Herbage is lightly covered with small hairs and occasionally has a thin, bluish wax. The inflorescence consists of clusters of several short-stalked flowers in the axils of the upper leaves. The tubular corolla is flared and two-lipped at the mouth, 25-35 mm long, and bright blue. The lance-shaped calyx segments taper to a long tip, are 7-11 mm long, and have a narrow, white margin. The anthers are hairy with short pubescence, and the staminode is glabrous. Flowering generally occurs from early June-late July, depending on climatic conditions and elevation. Fruits mature and dehisce during August-early September.

Lemhi beardtongue is a perennial herb, 3-7 dm tall, with one to several stout stems from a branched caudex; herbage often finely hirtellous-puberulent at least in part; leaves entire, the basal ones clustered, up to $15-20 \mathrm{~cm}$ long and $1-2.5 \mathrm{~cm}$ wide, with petiolate, oblanceolate to narrowly elliptic blades; cauline leaves sessile, opposite, mostly lanceolate, up to $10-12 \mathrm{~cm}$ long and 1-2 cm wide; inflorescence glabrous, of several to many loose verticillasters, more or less secund in life; calyx 7-11 mm long, the segments lanceolate to narrowly ovate, evidently but not strongly scarious-margined below, tapering to a longacuminate or subcaudate tip; corolla bright blue to purplish, 25-35 mm long, about $1.0 \mathrm{~cm}$ wide at the mouth; pollen sacs $1-3 \mathrm{~mm}$ long, divaricate, evidently dentate-ciliate along the sutures, pubescent near the connective and on the side away from dehiscence; staminode glabrous; capsules about 10-15 mm long; seeds about 2-3 $\mathrm{mm}$ long (Shelly 1987).

Penstemon cyaneus is very similar but has sepals that are rounded at the tip and nearly as broad as long. Penstemon cyananthus has smaller flowers only $15-25 \mathrm{~mm}$ long.

HABITAT: In Montana, Penstemon lemhiensis occurs on moderate to steep, east- to southwest-facing slopes, often on open soils. In Beaverhead County, it typically grows below or near the lower extent of Douglas-fir and/or lodgepole pine forests. Associated vegetation is typically dominated by big sagebrush and bunchgrasses, including western wheatgrass and Idaho fescue. Within these habitats, Lemhi

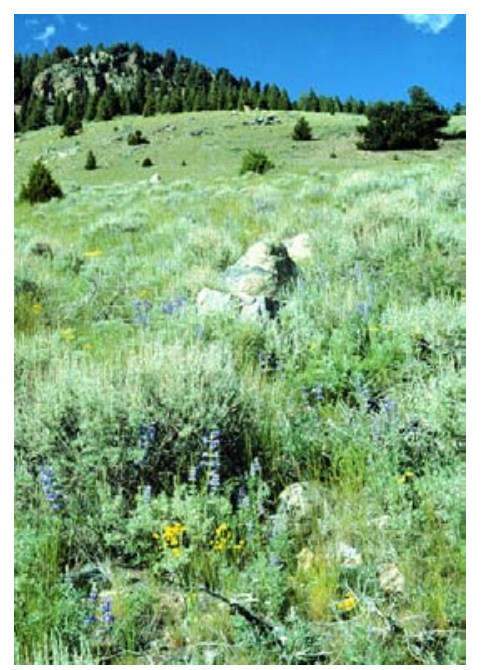

Penstemon lemhiensis habitat 
beardtongue prefers areas that are more sparsely vegetated (Shelly 1990). In the northeastern Pioneer Mountains, it inhabits forb-dominated openings in lodgepole pine, and to a lesser extent Douglas-fir, forests; big sage is typically not present, and prominent forbs include Astragalus miser, Pedicularis contorta and Townsendia parryi.

The species is not restricted to any particular geological substrate; it has been found on granitic soils, as well as limestone and other sedimentary substrates. Soils are often very gravelly, however soil texture is highly variable and ranges from sand to fine clay. Field surveys from 1986-1989 indicate that it is most commonly found on gravelly loams. At some sites the populations can occur partially or entirely on roadbanks.

ECOLOGY: Lemhi beardtongue has some degree of adaptation to natural disturbance, as evidenced by its preference for more open habitats, such as rock outcrops and steep, rocky slopes with natural soil slippage (Shelly 1990). This adaptation is even clearer where plants have colonized roadbanks.

Studies have shown that seed germination and recruitment are the most critical life history stages (Heidel and Shelly 2001). In general, both flowering and germination are higher in cool, wet springs and early summers, and are correlated with April-June mean maximum monthly temperature and net precipitation in the same period. Mortality of established plants is highest in hot, dry years (Heidel and Shelly 2001).

MANAGEMENT CONSIDERATIONS: Monitoring studies on National Forest and BLM lands in southwest Montana have documented sharp declines in some of the largest populations east of the Continental Divide (Shelly 1990; Achuff 1992). One relatively small monitored population was restricted to roadcut habitat and was similarly in decline. Continued declines were projected in the absence of seed germination and recruitment at part or all of the other three sites. Waxing and waning of populations is expected for native ruderal species such as Penstemon lemhiensis.

Fire suppression has been suggested as a factor in the rangewide decline of Lemhi beardtongue (Moseley et al. 1990). The species is thought to increase in abundance under certain fire regimes, based on qualitative observations after a wildfire in Salmon National Forest and monitoring of a prescribed burn in Big Hole National Monument, where it increased a decade after the burn but disappeared from an adjoining untreated area (Heidel and Shelly 1997). Another monitoring study at Badger Pass found that recruitment increased dramatically after fire treatment, consistent with the tendency of fire-adapted species to show recruitment from seedbanks when fire removes accumulated litter and reduces competition. Based on these studies, prescribed burning has been recommended where Lemhi beardtongue occupies deep-soil rangeland habitats east of the Continental Divide, which are prone to an increasing density of Artemisia tridentata in the absence of fire (Heidel and Shelly 2001).

Spotted knapweed is a widespread invader in this species' habitat, particularly west of the Continental Divide. Where Lemhi beardtongue occurs in the Bitterroot National Forest, management of the species with fire is problematic because of the high potential for noxious weeds to expand after fire (Heidel and Shelly 2001). Although herbicides can be used to control invasive species, their effect on the pollinators of Lemhi beardtongue is not known. It is an obligate out-crosser, primarily dependent on insect pollination, and relatively small, isolated populations may already be at a disadvantage in their ability to attract effective pollinators (Shelly 1990). Spotted knapweed has not yet invaded populations in Beaverhead and Silver Bow Counties, though it has been observed in nearby areas where it can still be controlled without direct impact to the species.

Grazing exists throughout much of the species' range in southwestern Montana, and monitoring transects have been established to assess its effect on populations. The habitat of Lemhi beardtongue was 
historically impacted by mining at some locations, and renewed gold mining activity could pose a future threat (Shelly 1990) [from Lesica 2003]. 
Physaria saximontana var. dentata (Brassicaceae)

Rocky Mountain bladderpod

BLM Status: None

Heritage ranking: G3T3/S3

RANK JUSTIFICATION: Rocky mountain bladderpod is a state endemic known from several counties scattered across central and western Montana.

IDENTIFICATION: The species is perennial with a taproot and usually simple caudex; silvery pubescent throughout with stellate trichomes with forked rays. Stems few to numerous, prostrate to decumbent, and 3-10 cm long. Basal leaves rosulate, densely pubescent with appressed trichomes, petiolate, $1.5-3 \mathrm{~cm}$ long, $8-14 \mathrm{~mm}$ wide, petiole winged, blade orbicular to broadly obovate, obtuse with broad, obscure, tooth-like angles on each side at the apex. Cauline leaves broadly spatulate to linearoblanceolate, entire, 1-1.5 cm long. Sepals narrowly oblong, 5-6 mm long. Petals yellow, spatulate, 8-10 $\mathrm{mm}$ long, 2-3 $\mathrm{mm}$ wide. Inflorescence condensed to slightly elongated. Fruiting pedicels divaricately ascending, straight to slightly curved, 6-10 mm long; siliques deeply lobed, inflated at maturity, sinus absent below, deep above, valves irregular, rounded, densely pubescent with spreading trichomes, 3-4 $\mathrm{mm}$ long, 1.5-2 mm wide. Styles 3-5 mm long; ovules 2-4 in each locule. Flowering and fruiting occur in June and July with fruits maturing into August.

The typical variety $P$. saximontana var. saximontana, which is currently known only from Wyoming, can be distinguished by its entire basal/rosette leaves and longer styles ( 3 or more times the length of the replum) vs. the toothed apical margins of the basal/rosette leaves of variety dentata and the shorter styles (1-2 times or less the length of the replum). The species is also very similar to $P$. didymocarpa, but can be separated by the lack of a basal sinus on the silique of $P$. saximontana.

HABITAT: Rocky mountain bladderpod is typically found in limestone-derived talus, fellfields, and gravelly slopes at moderate to high elevations.

Additional information on management considerations for the species, as well as information on the species' ecology in Montana is not available at this time. 
Townsendia spathulata (Asteraceae)

\section{Sword townsendia}

BLM Status: None

Heritage ranking: G3/S3

RANK JUSTIFICATION: Sword townsendia has a limited distribution in limestone areas of southwest and south-central Montana.

IDENTIFICATION: Sword townsendia is a perennial $1-5 \mathrm{~cm}$ tall with a stemless crown surmounting a taproot. Leaves are spathulate, $1-1.5 \mathrm{~cm}$ long and $2-4 \mathrm{~cm}$ wide, covered by dense, long hairs that give them a woolly

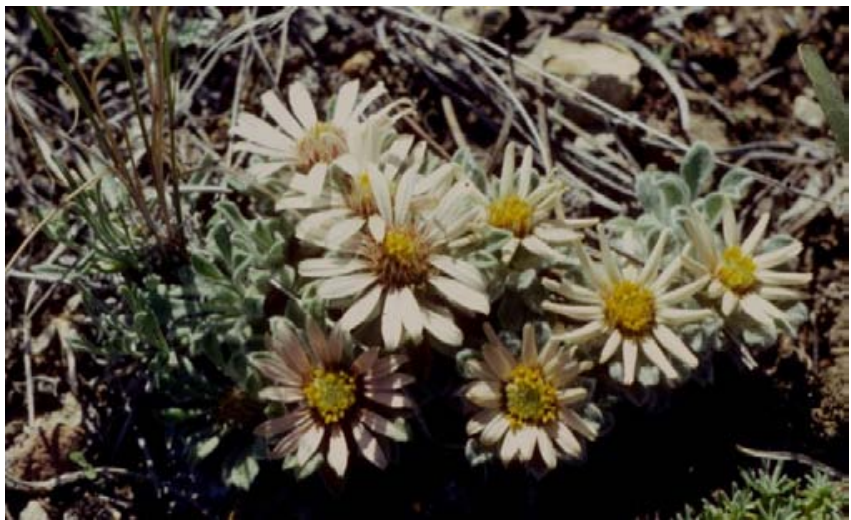

Townsendia spathulata appearance, and tightly clustered in a rosette. The 1-many flower heads are sessile, or solitary on leafless stalks. Ray flowers are 1-2 cm long, with a pale, off-white color. Flowering occurs in early May to late June. Plants flower and disperse fruit over a two-four week period.

Townsendia spathulata is distinguished from other Townsendia species in our area by its pale, off-white rays and spathulate leaves. This name has been misapplied in the past to include $T$. condensata, which is a high elevation regional endemic only known in Montana from Glacier National Park and the Absoroka - Beartooth region.

HABITAT: Sword townsendia is found on open, rocky, limestone-derived soils of slopes and windswept ridgetops in the valley and foothill zones, in mountain mahogany woodlands and cushion plant grasslands.

Additional information on management considerations for the species, as well as information on the species' ecology in Montana is not available at this time. 


\section{APPENDIX D. BUTTE FIELD OfFICE ELEMENT OCCURRENCE MAPS}





\section{BUTTE FIELD OFFICE ELEMENT OCCURRENCE MAPS}

Documented occurrences of Montana Natural Heritage Program Species of Concern known at the time of this report are displayed in the following maps. General map areas with known occurrences are referenced below by map number and page number. Additionally, Element Occurrences are listed alphabetically and referenced to map number. Mapped areas represent actual observed boundaries whenever possible. However, many occurrences are based on surveys or specimen collections that do not provide specific mapped boundaries. In these cases, boundaries are mapped according to TRS data, directions and/or provided coordinates, and the mapped boundaries do not represent the actual population boundaries but the area within which the occurrence is contained.

\section{LIST OF MAPS}

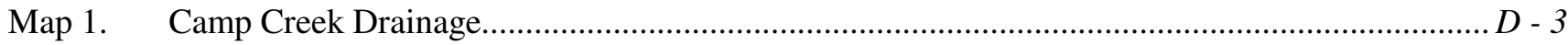
Brickellia oblongifolia $\mathrm{EO} \# 3$

Map 2. Soap Gulch $D-3$ Arabis fecunda $\mathrm{EO} \# 21$; Brickellia oblongifolia $\mathrm{EO}$ \#2

Map 3. MacLean Creek - Moose Creek areas ................................................................................ $D$ - 4 Carex idahoa $\mathrm{EO} \# 15$

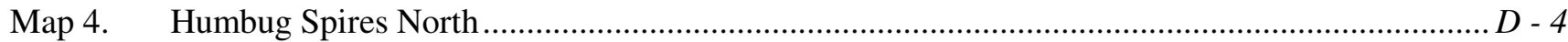
Arabis fecunda $\mathrm{EO} \# 16,17$

Map 5. Upper Moose Creek $D-5$ Arabis fecunda EO \#18; Carex idahoa EO \#22

Map 6. Maiden Rock - Goat Mountain area $D-5$ Brickellia oblongifolia EO \#1; Physaria saximontana var. dentata EO \#1; Townsendia spathulata $\mathrm{EO} \# 10$

Map 7. Wise River area $D-6$ Arabis fecunda $\mathrm{EO} \# 7,10,22$

Map 8. Deep Creek - Bear Creek area...... $D-6$ Penstemon lemhiensis EO \#57

Map 9. Chalk Bluff area $D-7$ Penstemon lemhiensis EO \#49

Map 10. Doherty Mountain area..... $D-7$ Delphinium bicolor ssp. calcicola EO \#5

Map 11. Cabin Gulch area $D-8$ Delphinium bicolor ssp. calcicola EO \#2

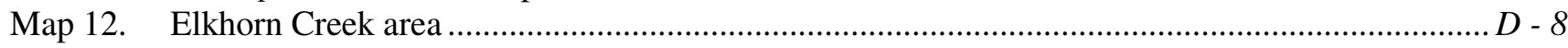
Delphinium bicolor ssp. calcicola EO \#1

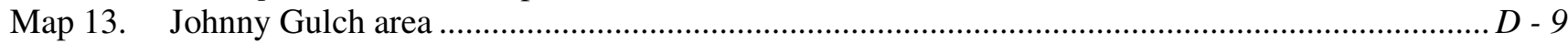
Delphinium bicolor ssp. calcicola EO \#3

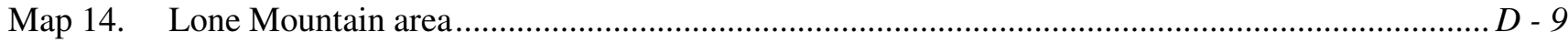
Delphinium bicolor ssp. calcicola $\mathrm{EO} \# 4$

Map 15. Limestone Hills $D-10$ Townsendia spathulata EO \#6

Map 16. Kimber Gulch - Beaver Creek area.................................................................................. $D$ - 10 Astragalus convallarius EO \#4

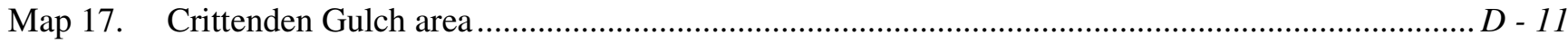
Astragalus convallarius EO \#8

Map 18. Montana City area $D-11$ Astragalus convallarius EO \#14 
Map 19. Hauser Dam area

$D-12$

Astragalus convallarius EO \#16

Map 20. Copper Butte area

$D-12$

Astragalus convallarius EO \#15

Map 21. Towhead Gulch area

$D-13$

Lesquerella klausii EO \#23

Map 22. Scratchgravel Hills

$D-13$

Astragalus convallarius EO \#9; Erigeron linearis EO \#4, 9; Lesquerella klausii EO \#35

Map 23. Tenmile Creek area.....

$D-14$

Astragalus convallarius EO \#13

Map 24. Johnson Creek area...

$D-14$

Erigeron linearis EO \#6

\section{ELEMENT OCCURRENCES BY MAP NUMBER}

Arabis fecunda $\mathrm{EO} \# 7$

Map 7

Arabis fecunda EO \#10

Map 7

Arabis fecunda EO \#16

Map 4

Arabis fecunda EO \#17

Map 4

Arabis fecunda EO \#18

Map 5

Arabis fecunda EO \#21

Map 2

Arabis fecunda EO \#22

Map 7

Astragalus convallarius EO \#4

Map 16

Astragalus convallarius EO \#8

Map 17

Astragalus convallarius EO \#9

Map 22

Astragalus convallarius EO \#13

Map 23

Astragalus convallarius EO \#14

Map 18

Astragalus convallarius EO \#15

Map 20

Astragalus convallarius EO \#16

Map 19

Brickellia oblongifolia EO \#1

Map 6

Brickellia oblongifolia EO \#2.

Map 2

Brickellia oblongifolia EO \#3

Map 1

Carex idahoa EO \#15

Map 3

Carex idahoa EO \#22 .

Map 5

Delphinium bicolor ssp. calcicola EO \#1

Map 12

Delphinium bicolor ssp. calcicola EO \#2

Map 11

Delphinium bicolor ssp. calcicola EO \#3

Map 13

Delphinium bicolor ssp. calcicola $\mathrm{EO} \# 4$

Map 14

Delphinium bicolor ssp. calcicola EO \#5

Map 10

Erigeron linearis EO \#4.

Map 22

Erigeron linearis EO \#6.

Map 24

Erigeron linearis EO \#9.

Map 22

Lesquerella klausii EO \#23

Map 21

Lesquerella klausii EO \#35.

Map 22

Penstemon lemhiensis EO \#49

Map 9

Penstemon lemhiensis EO \#57

Map 8

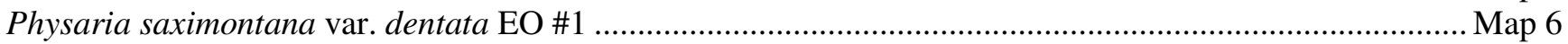

Townsendia spathulata EO \#6

Map 15

Townsendia spathulata EO \#10

Map 6 
Map 1. Camp Creek Drainage (Melrose and Wickiup Creek Quads).

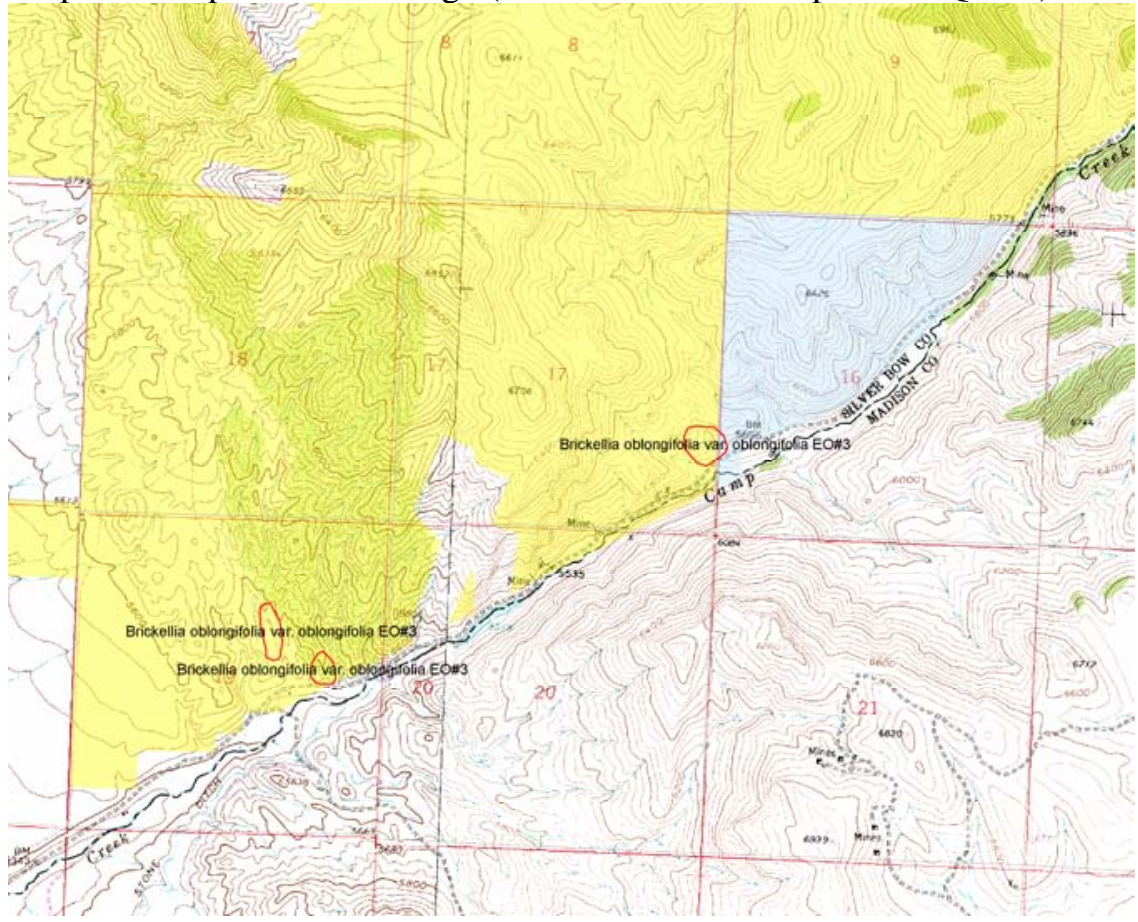

Map 2. Soap Gulch (Melrose Quad).

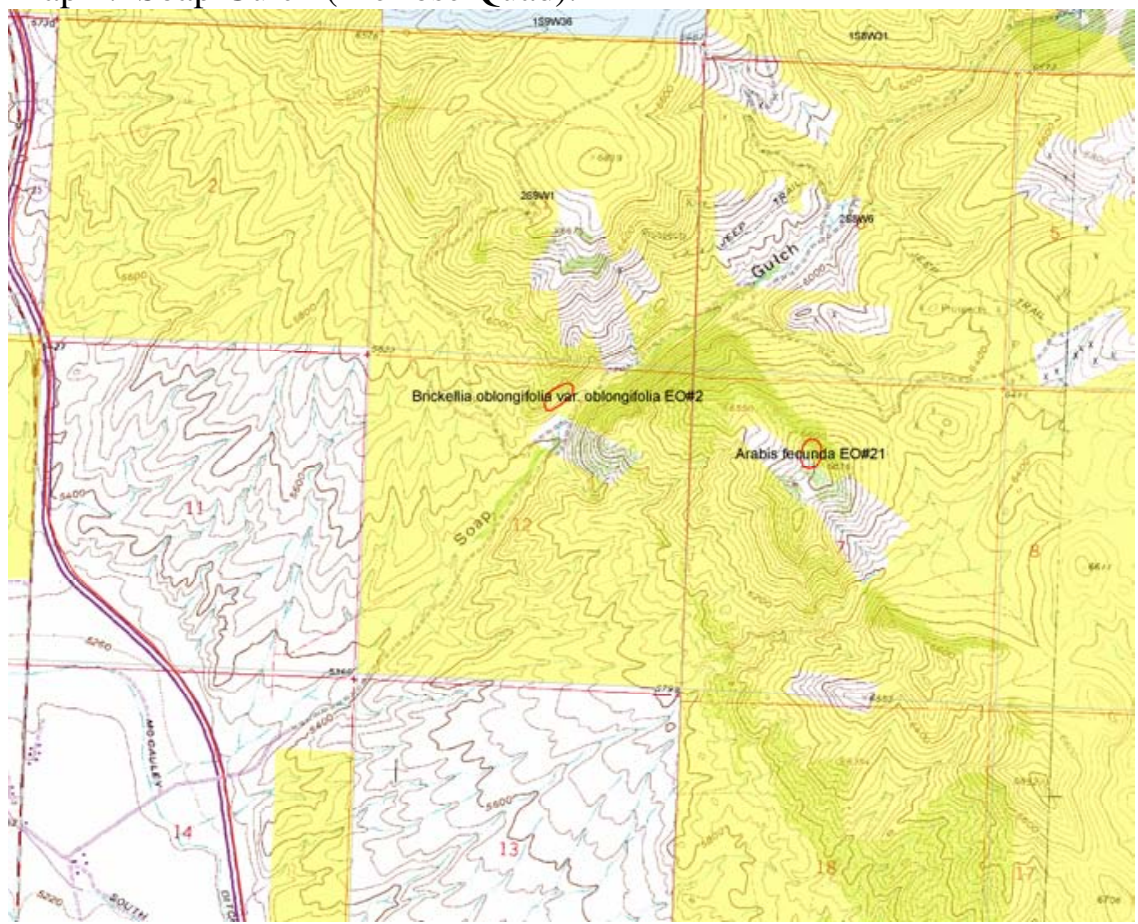


Map 3. MacLean Creek - Moose Creek areas (Melrose Quad).

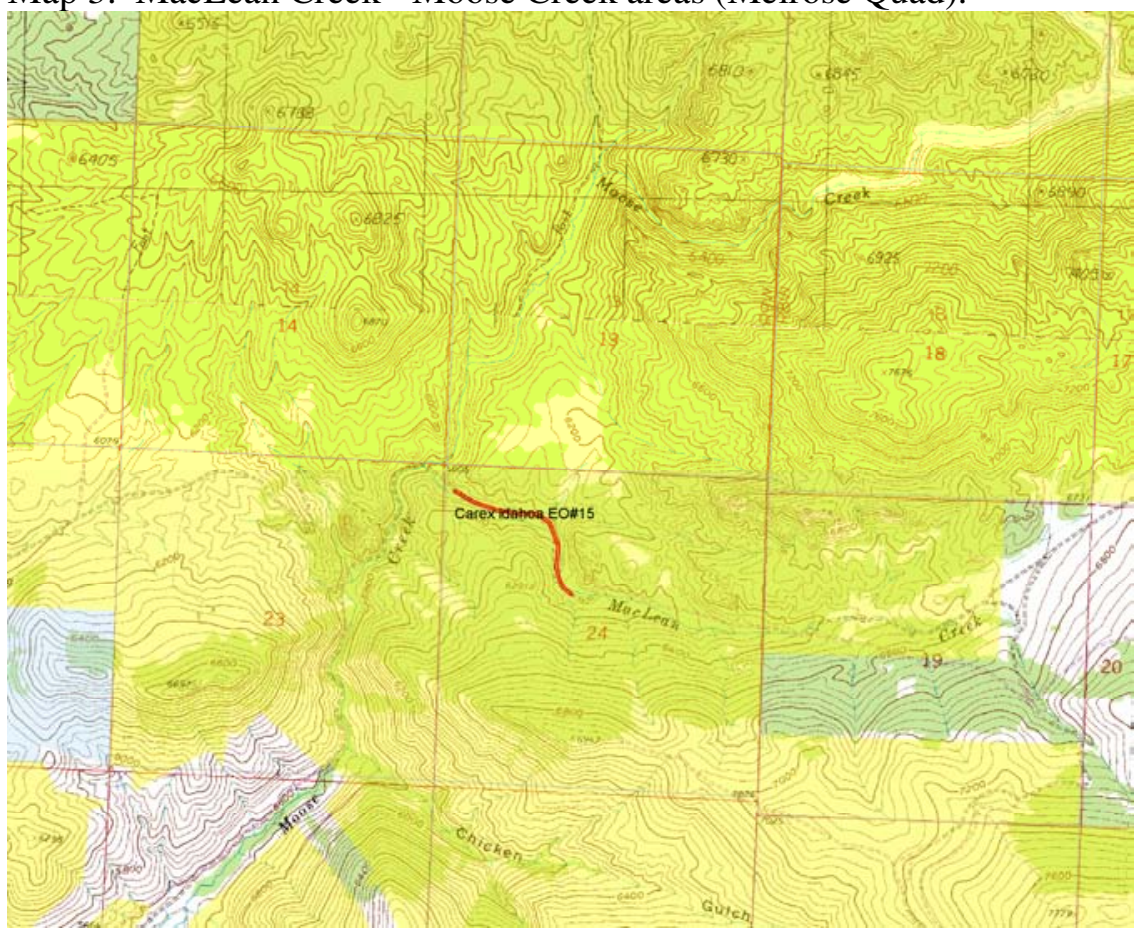

Map 4. Humbug Spires North area (Tucker Creek Quad).

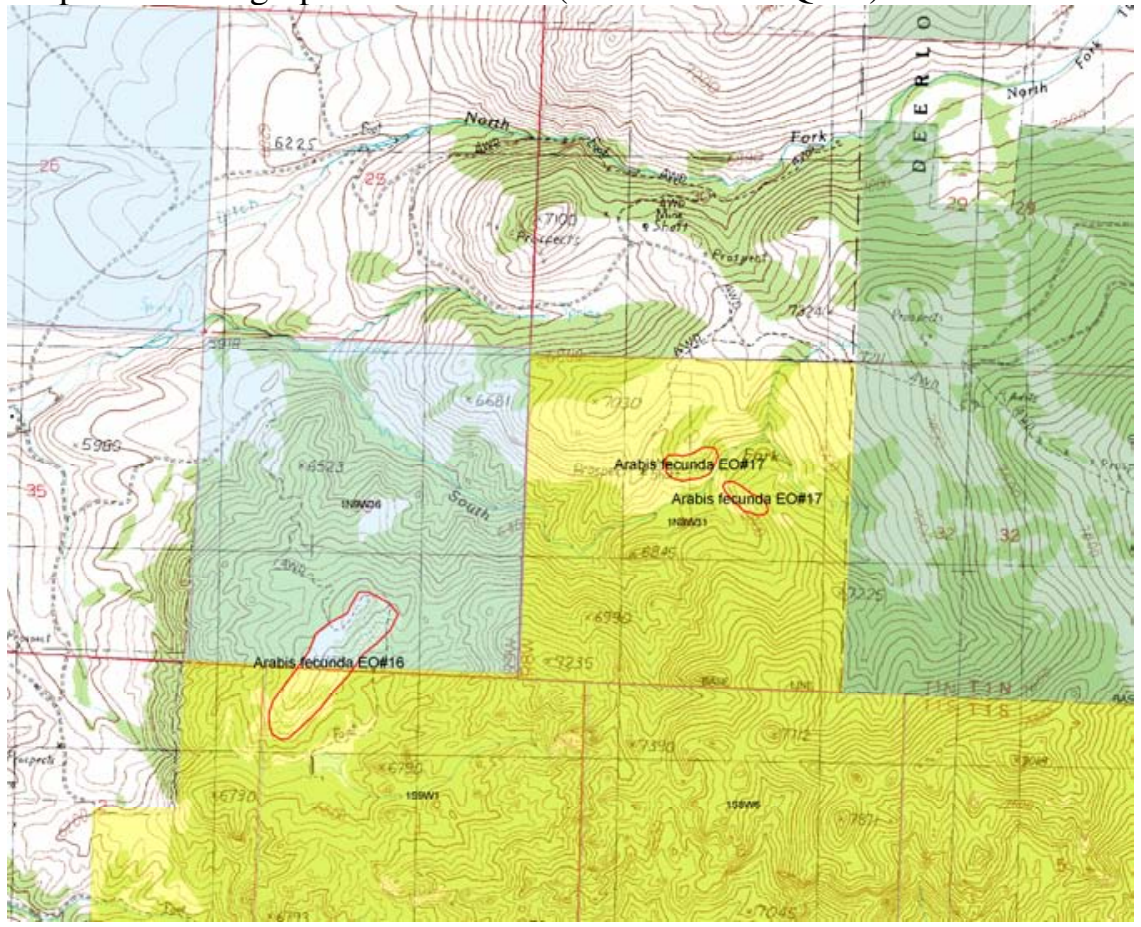


Map 5. Upper Moose Creek (Mount Humbug Quad).

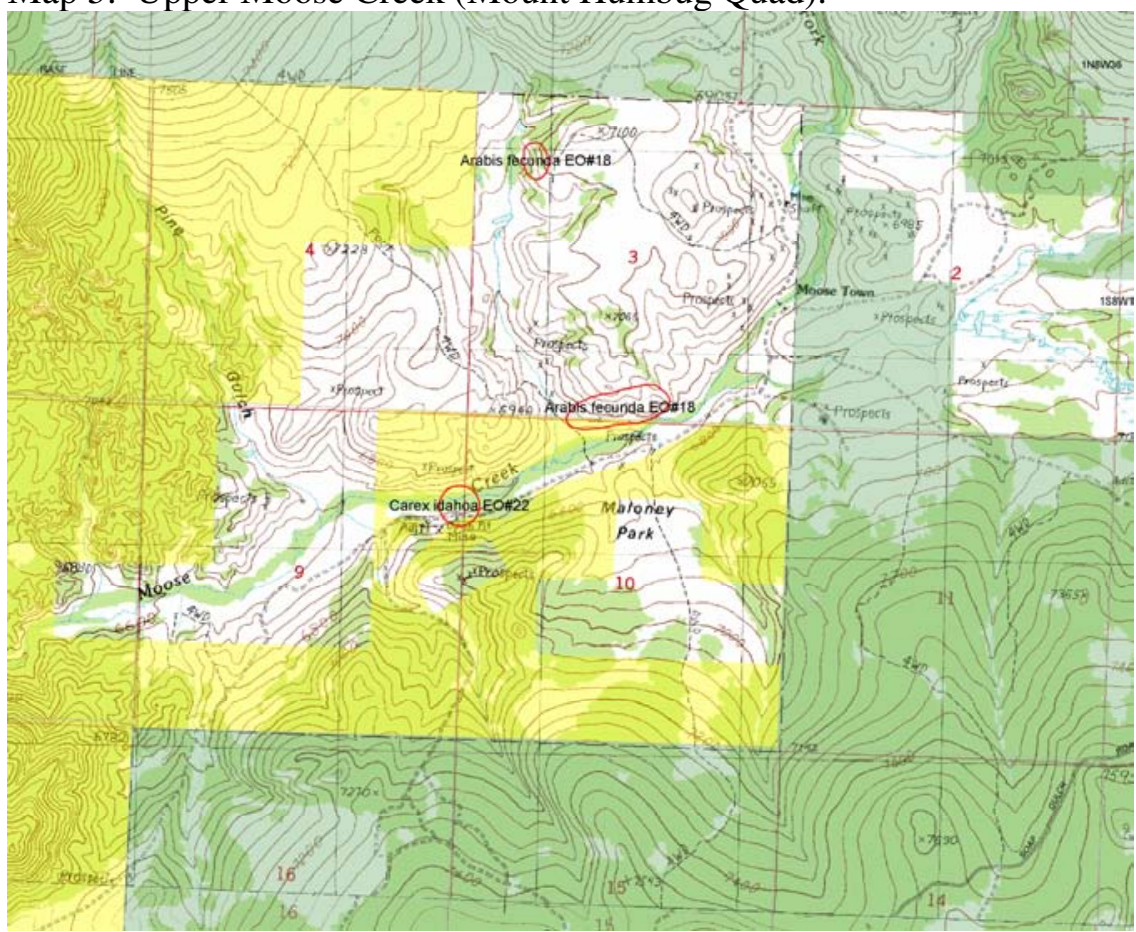

Map 6. Maiden Rock - Goat Mountain area (Melrose Quad).

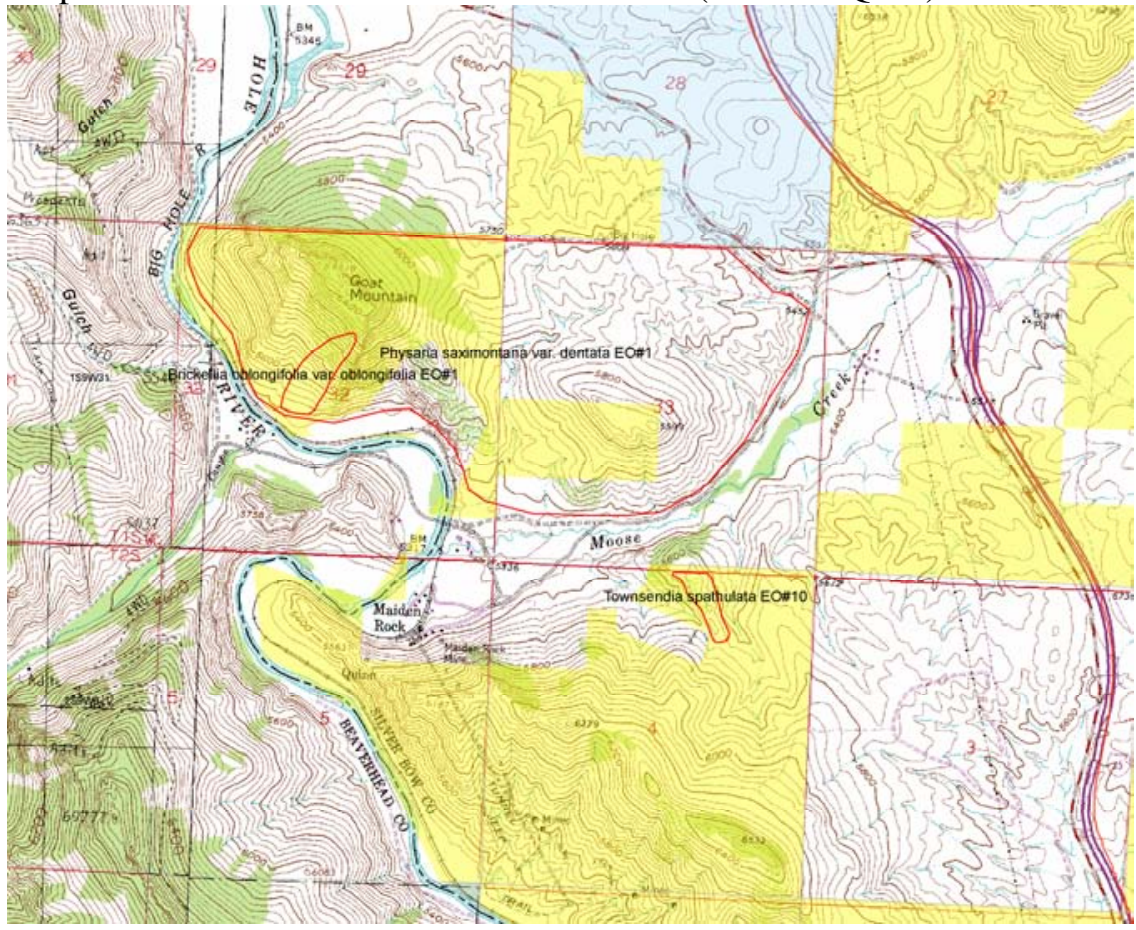


Map 7. Wise River area (Wise River and Dewey Quads).

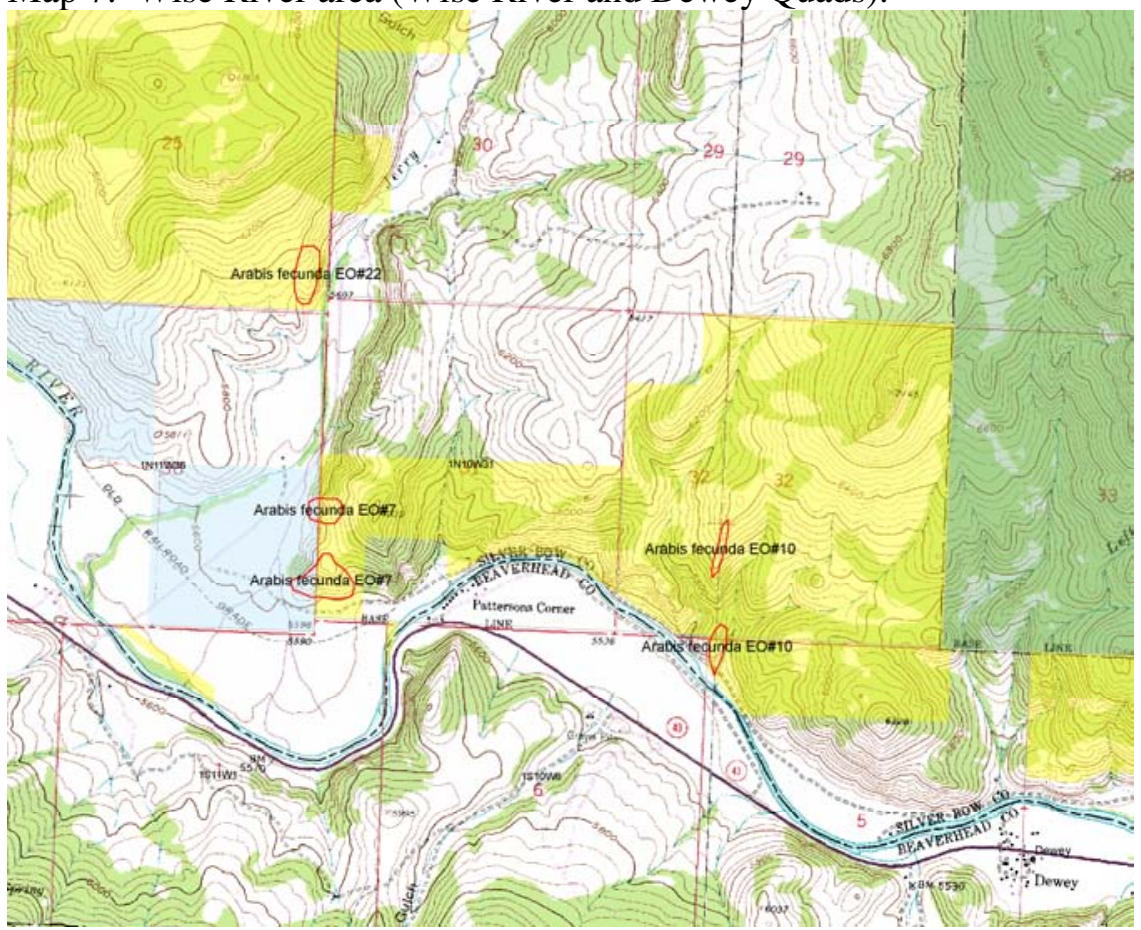

Map 8. Deep Creek - Bear Creek area (Lincoln Gulch Quad).

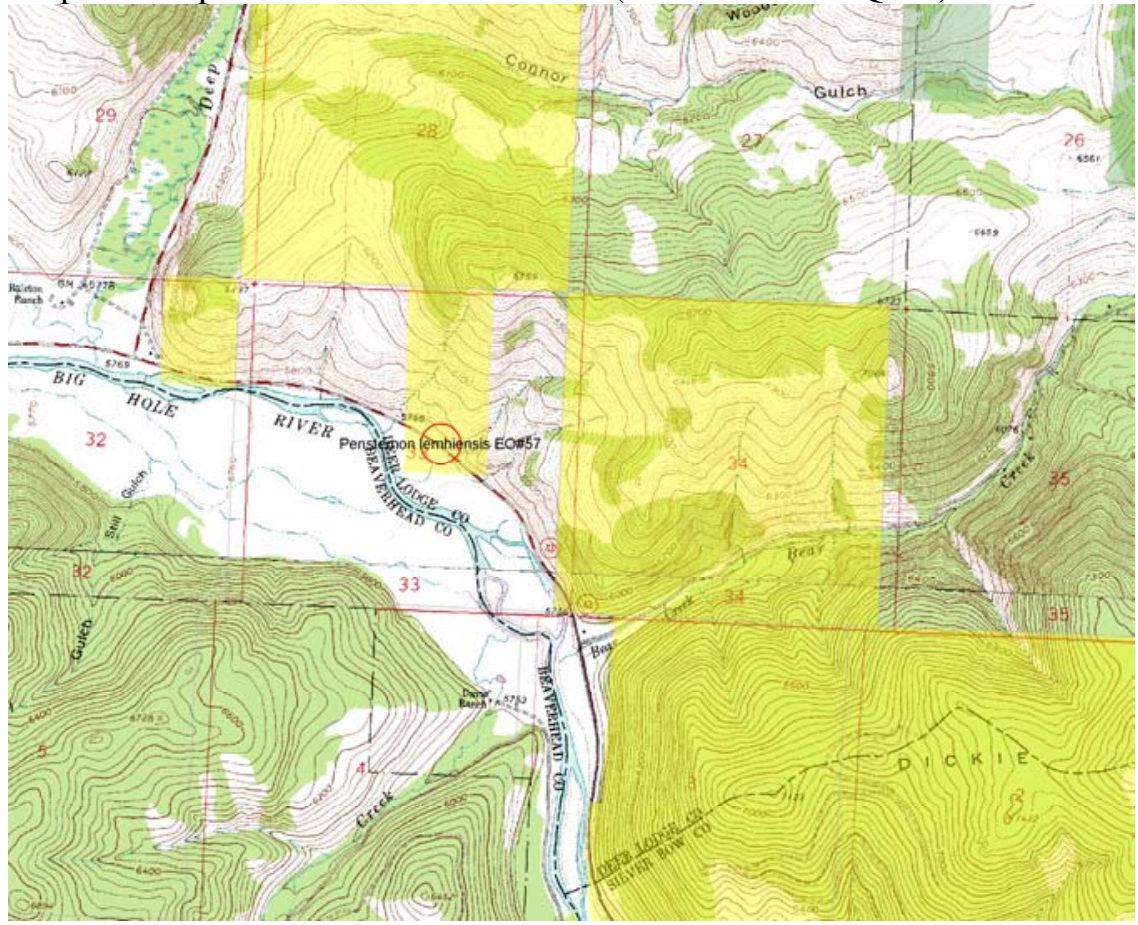


Map 9. Chalk Bluff area (Pine Hill Quad).

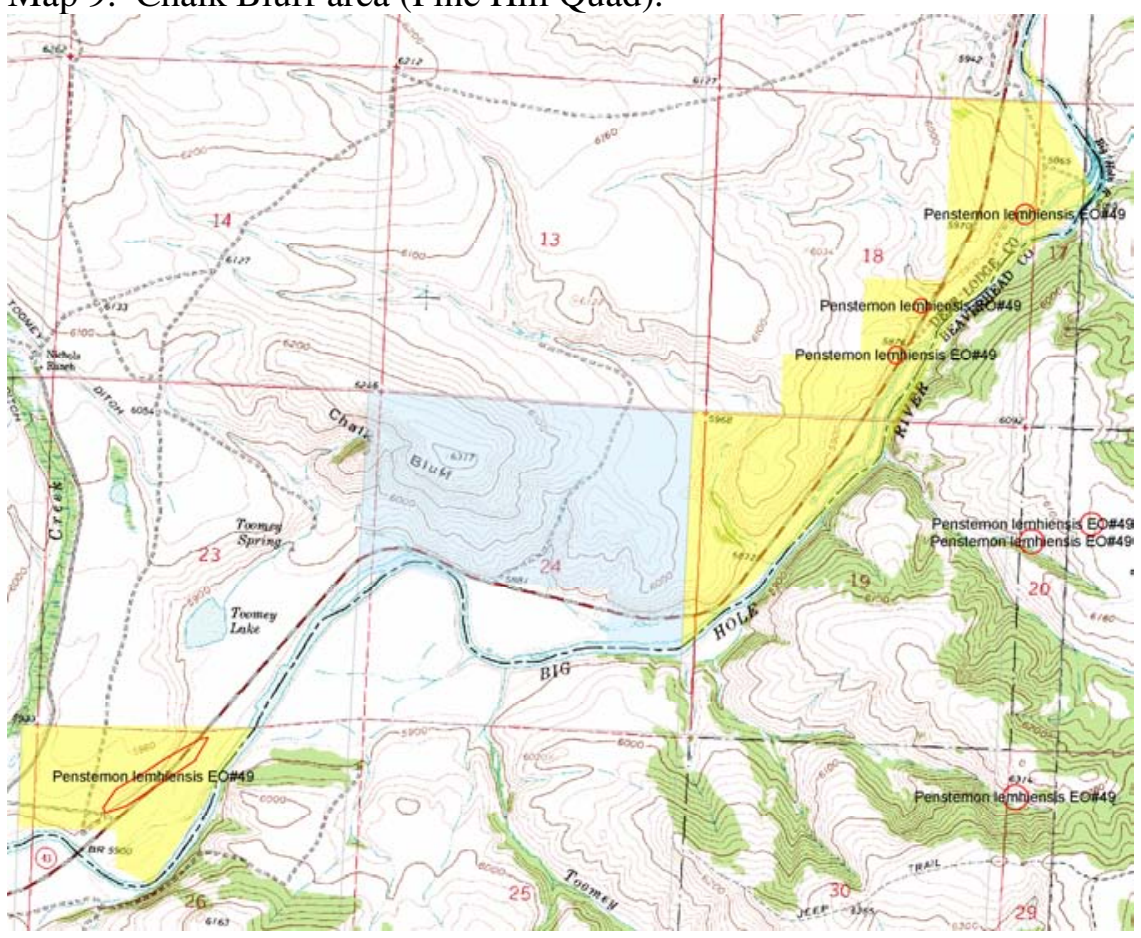

Map 10. Doherty Mountain area (Doherty Mountain and Jefferson Island Quads).

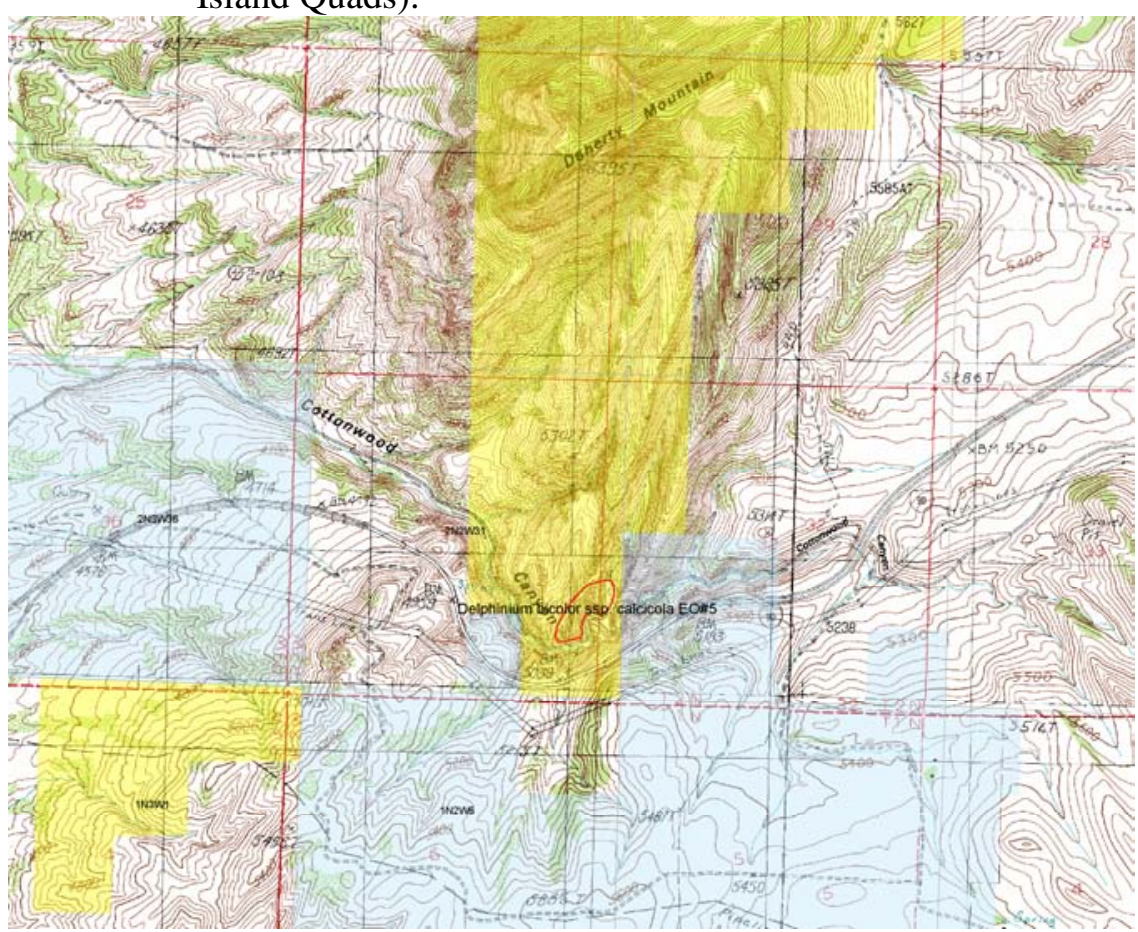


Map 11. Cabin Gulch area (Tacoma Park and Dunn Creek Quads).

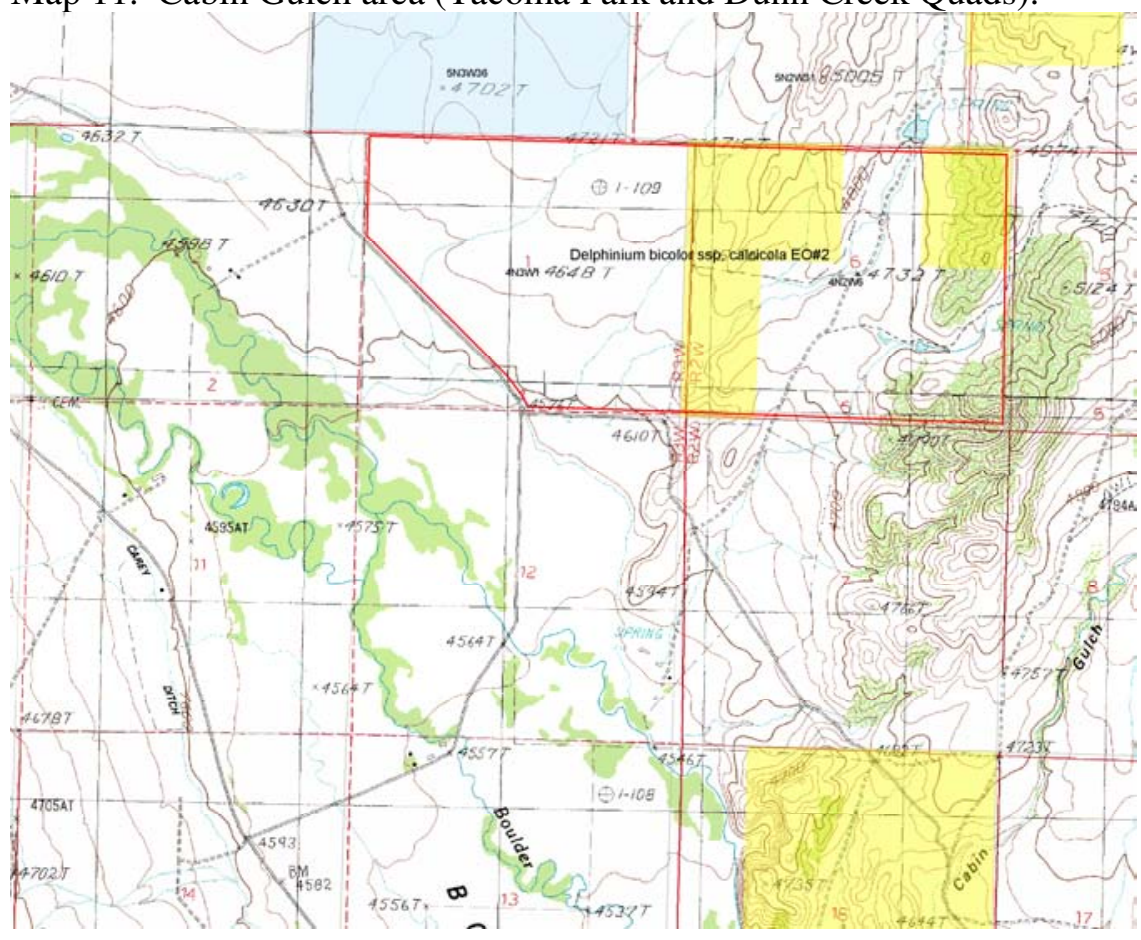

Map 12. Elkhorn Creek area (Tacoma Park Quad).

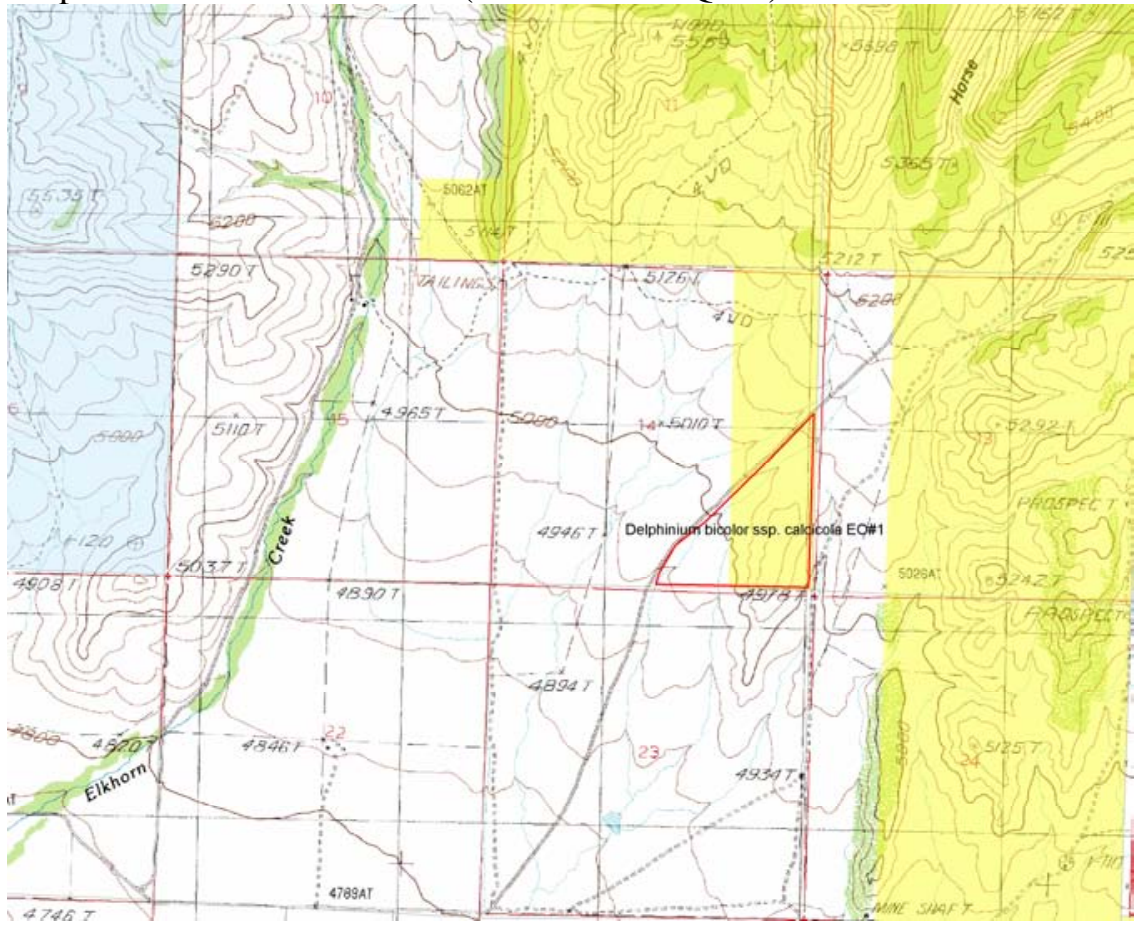


Map 13. Johnny Gulch area (Radersburg Quad).

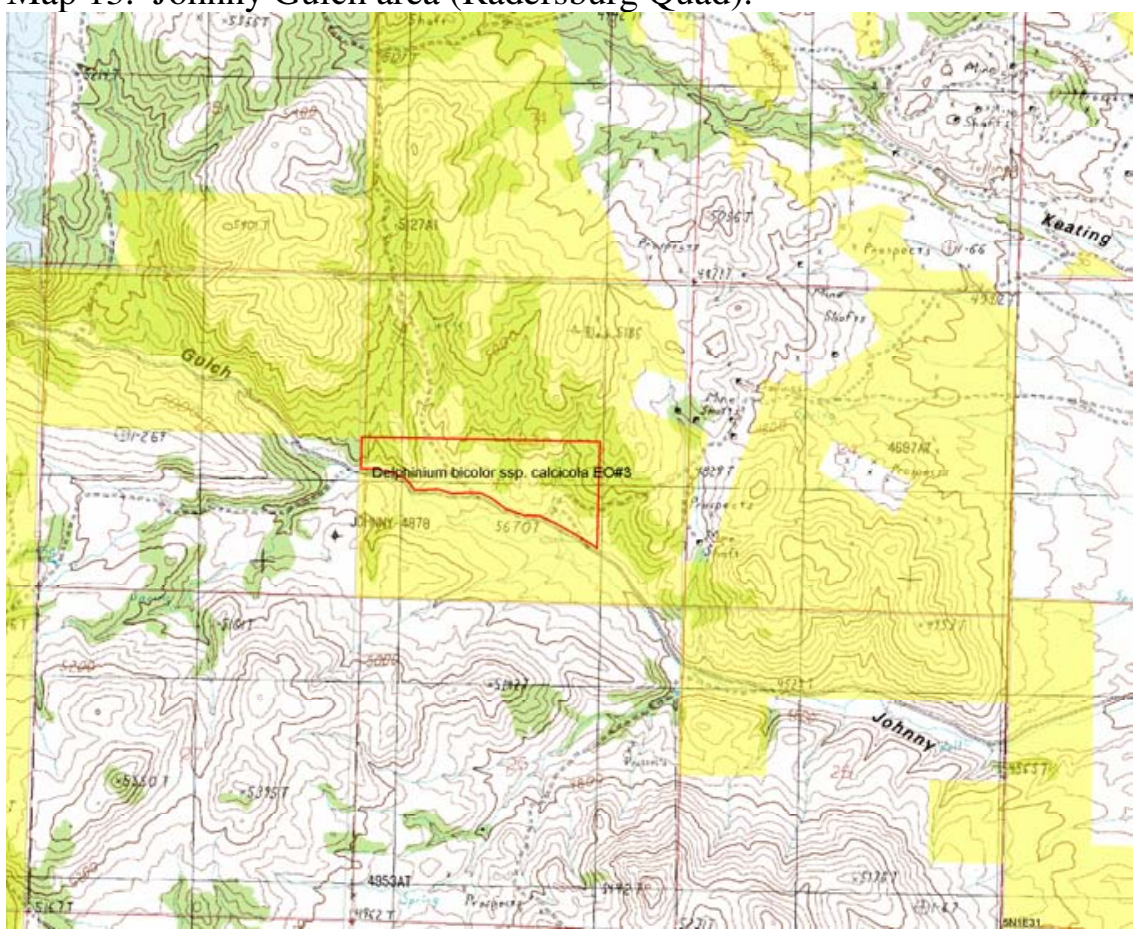

Map 14. Lone Mountain area (Radersburg and Radersburg SW Quads).

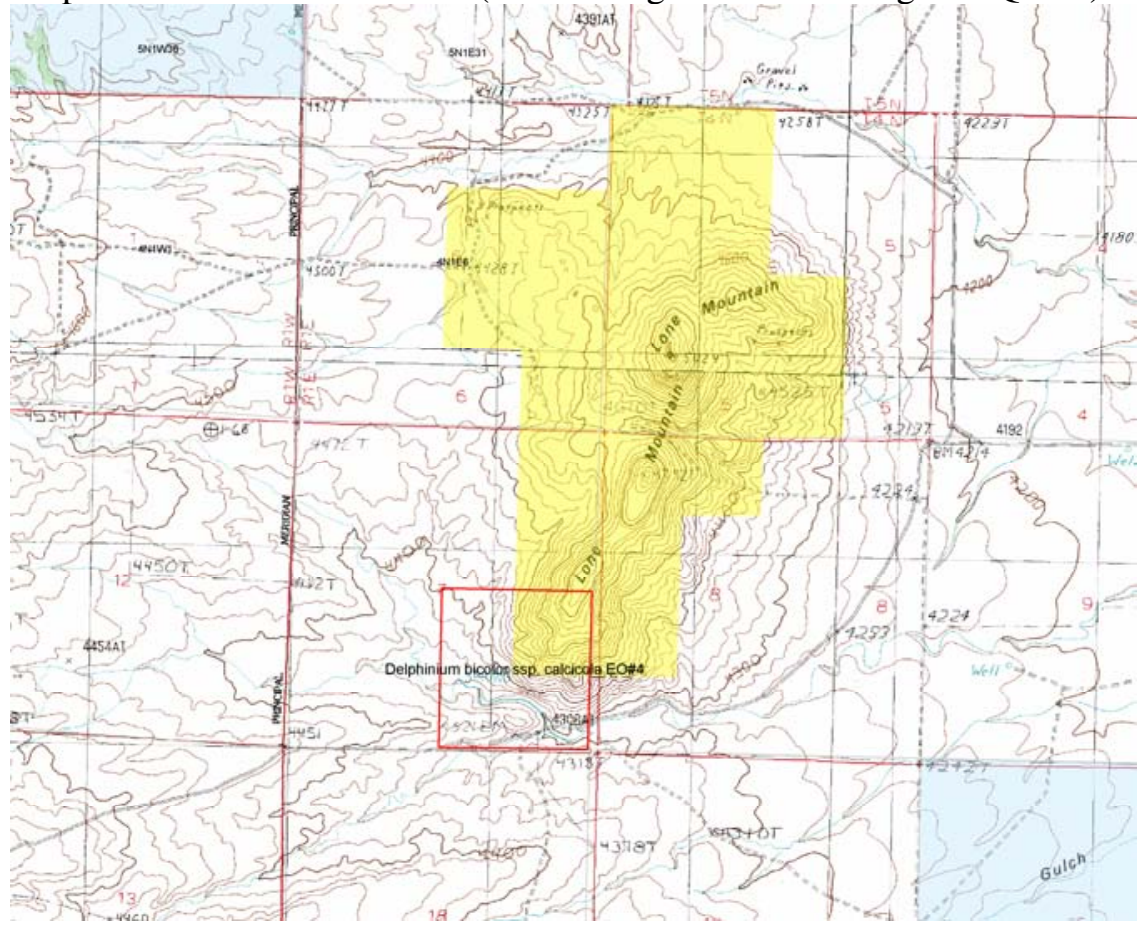


Map 15. Limestone Hills (Townsend, Giant Hill, Parker and Radersburg Quads).

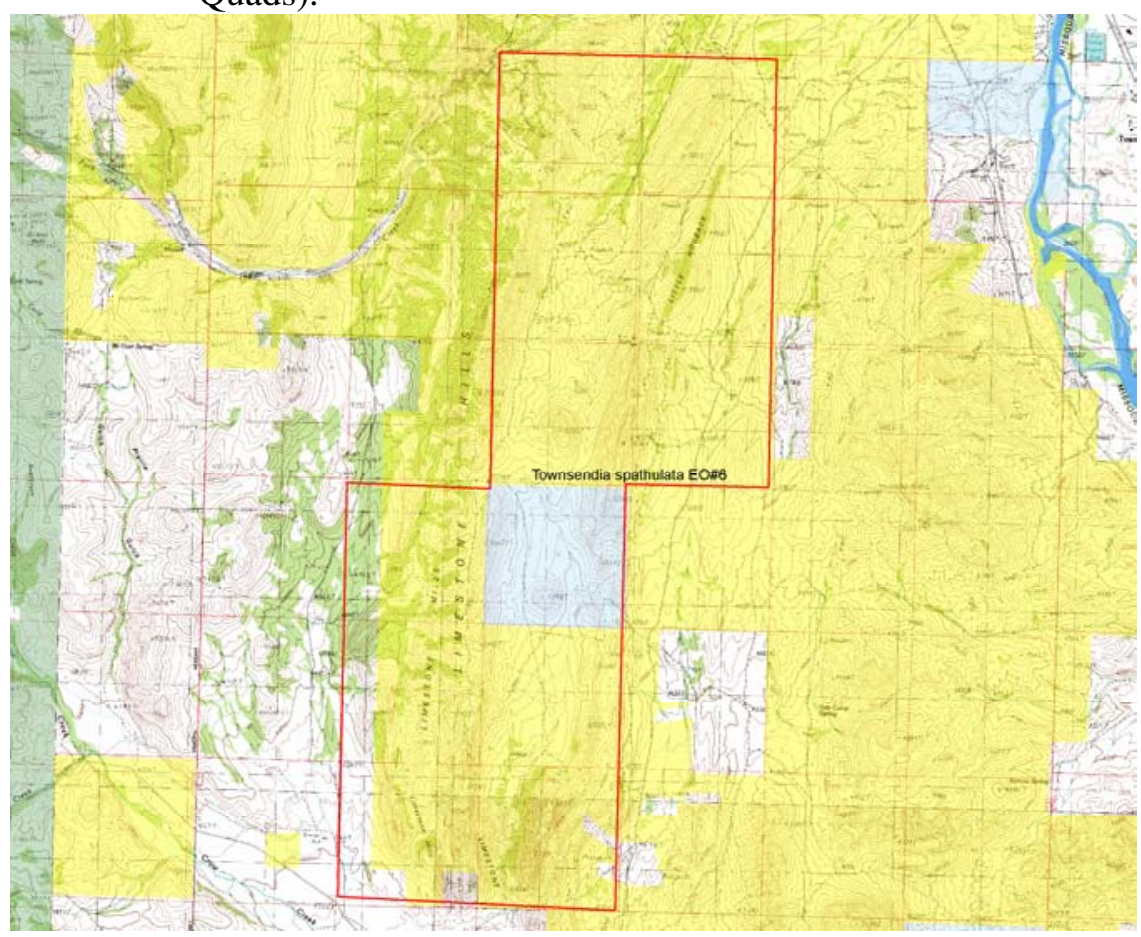

Map 16. Kimber Gulch - Beaver Creek area (Winston Quad).

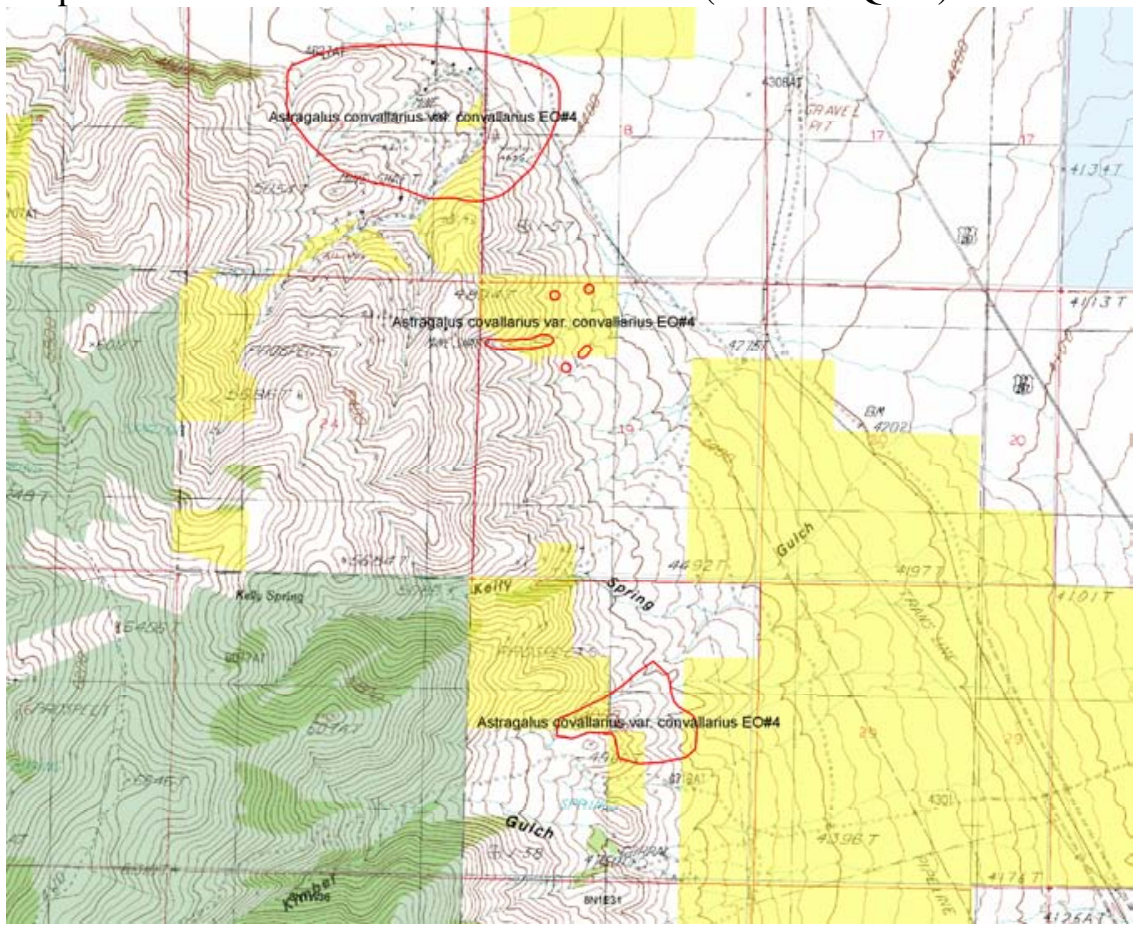


Map 17. Crittenden Gulch area (Canyon Ferry SW Quad).

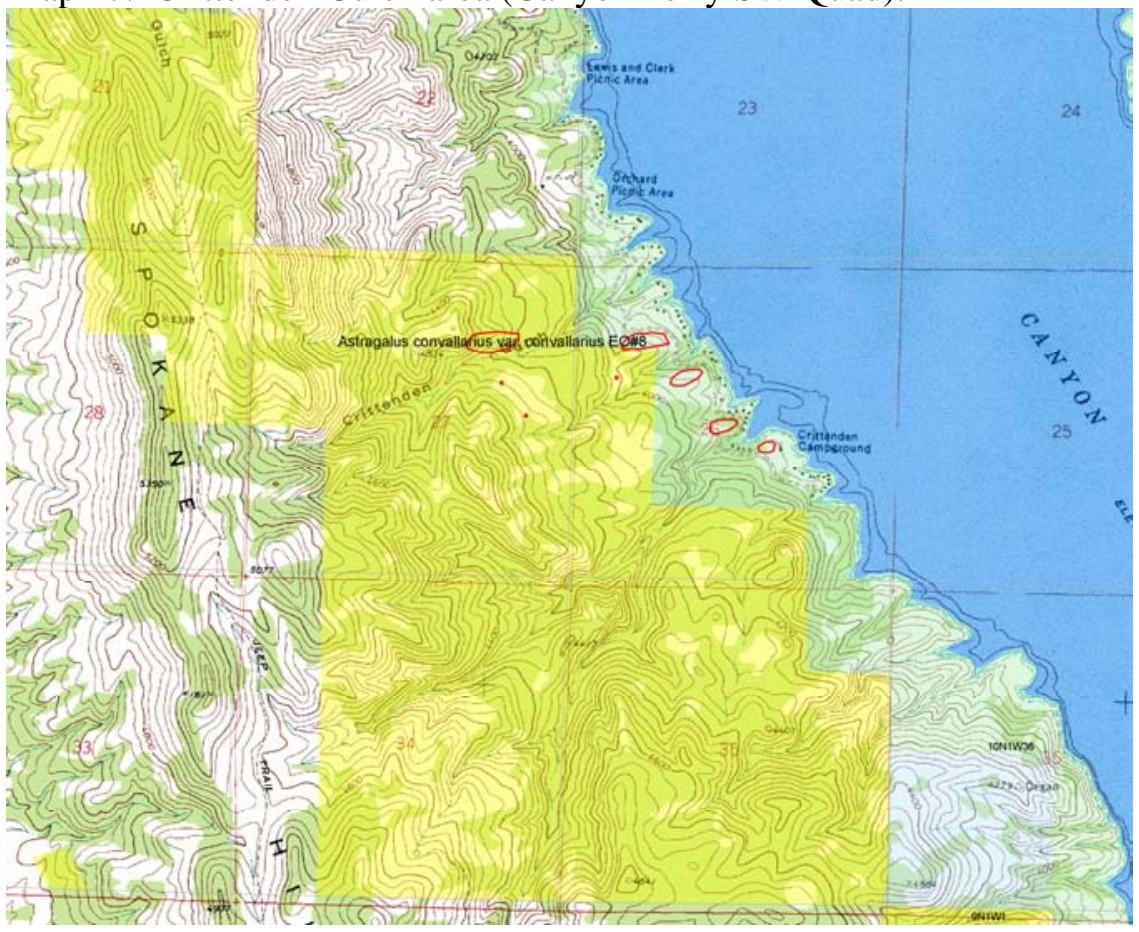

Map 18. Montana City area (East Helena Quad).

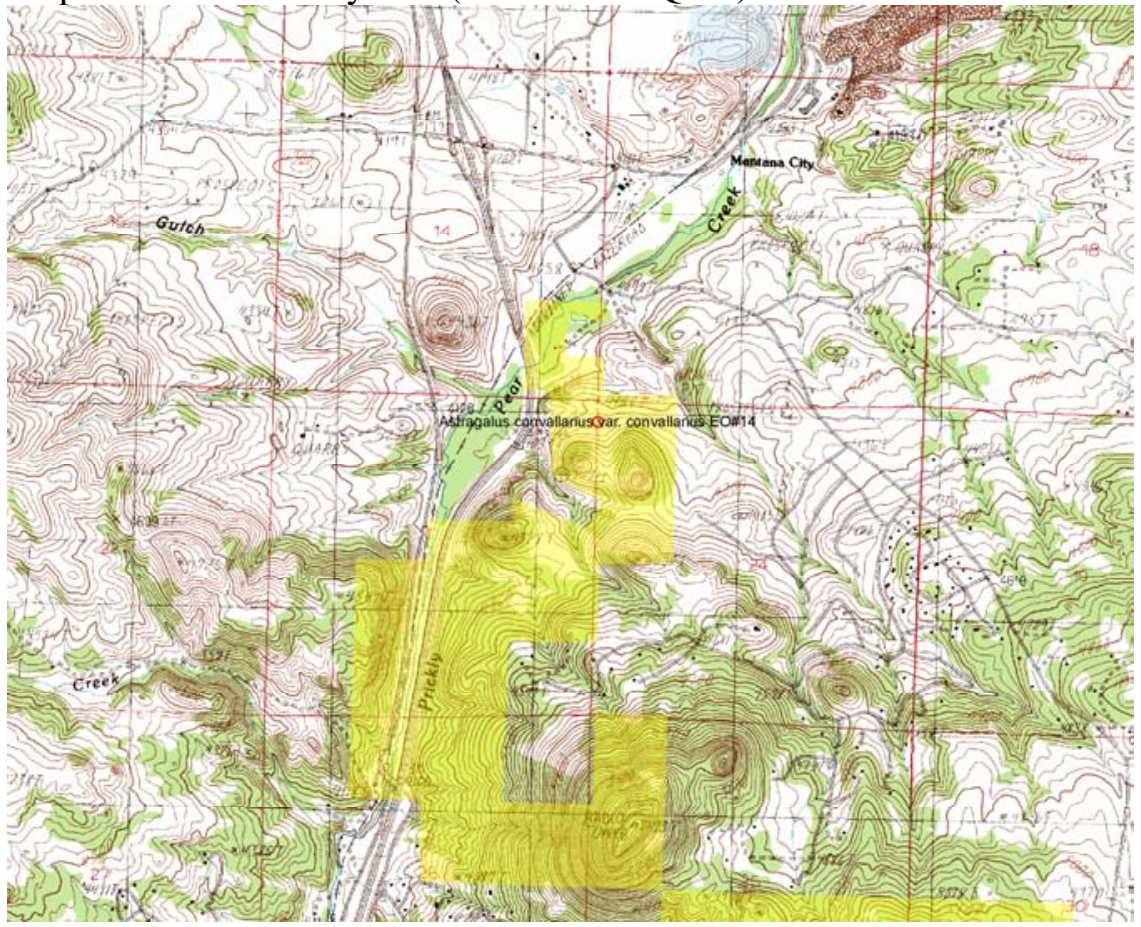


Map 19. Hauser Dam area (Upper Holter Lake Quad).

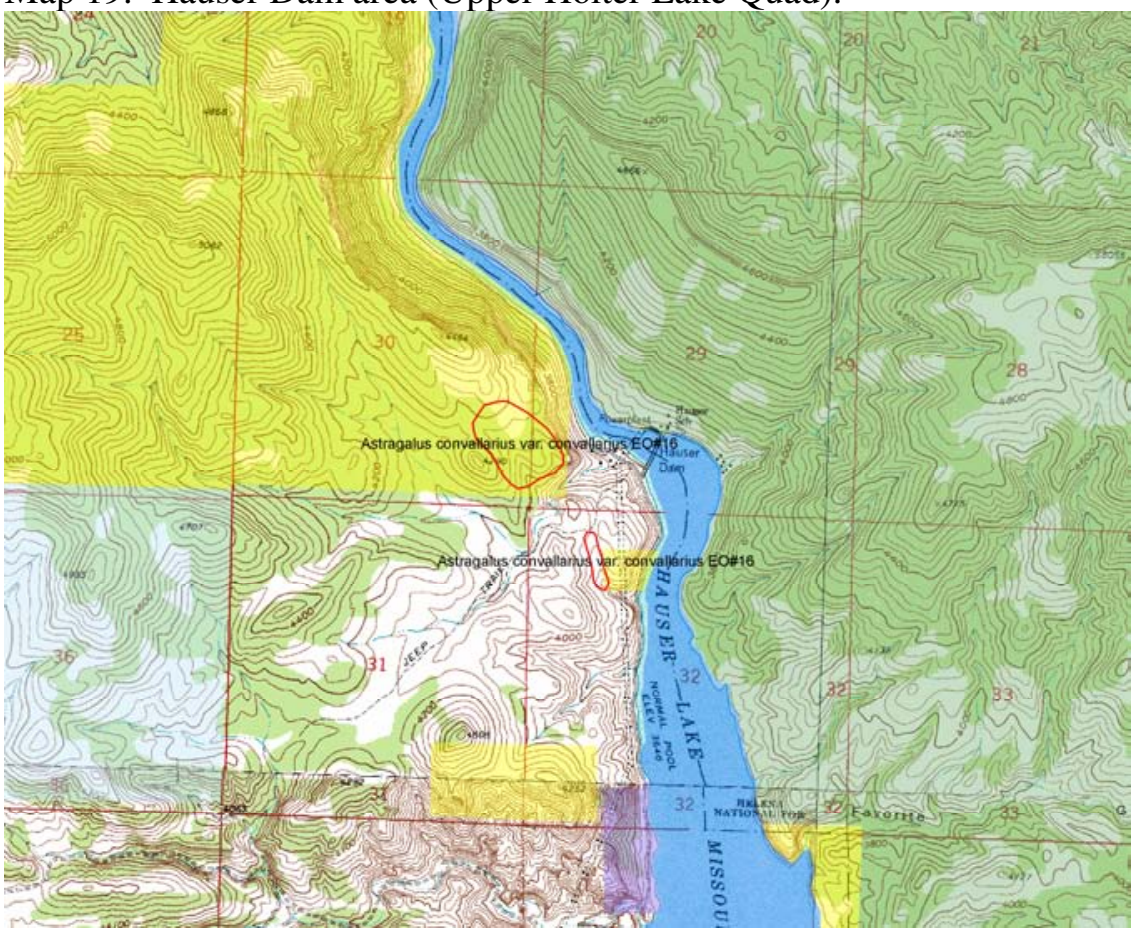

Map 20. Copper Butte area (Upper Holter Lake and Rattlesnake Mountain Quads).

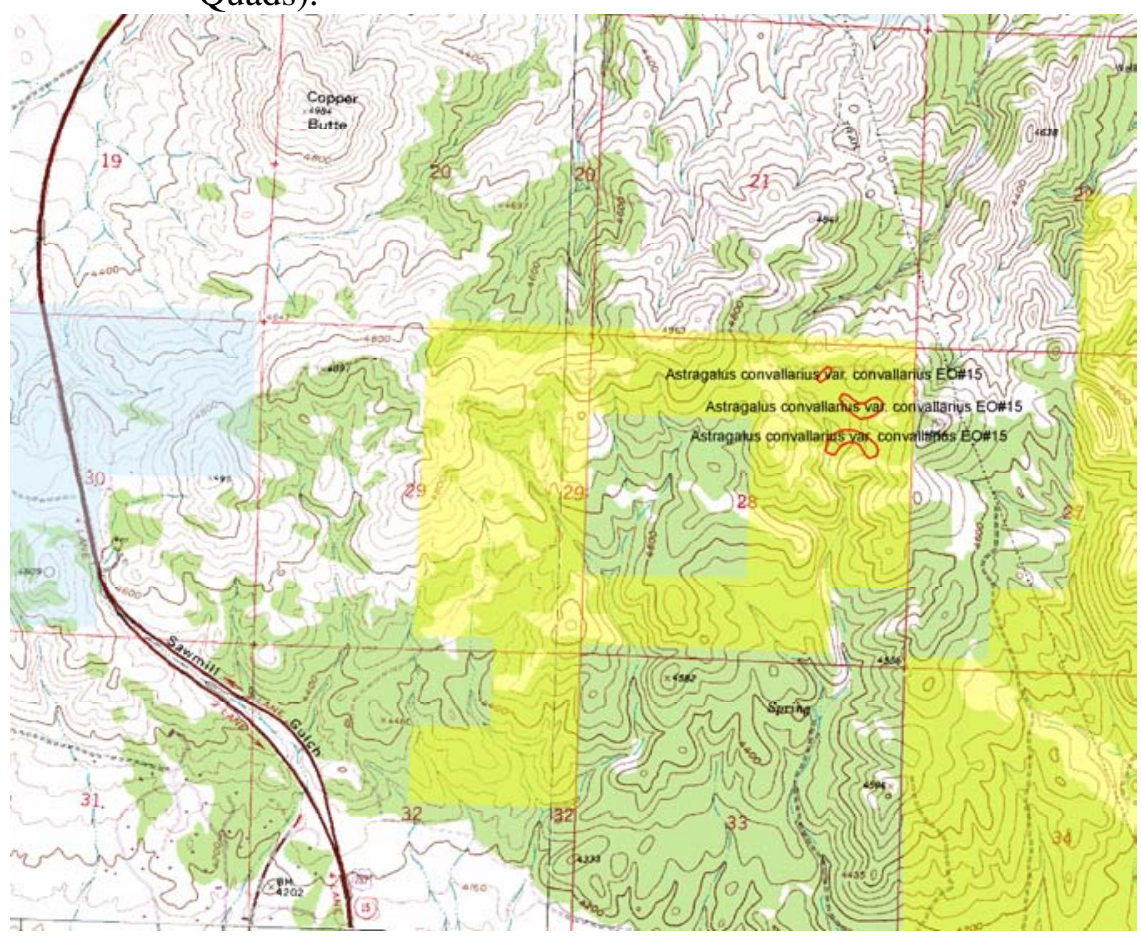


Map 21. Towhead Gulch area (Sheep Creek Quad).

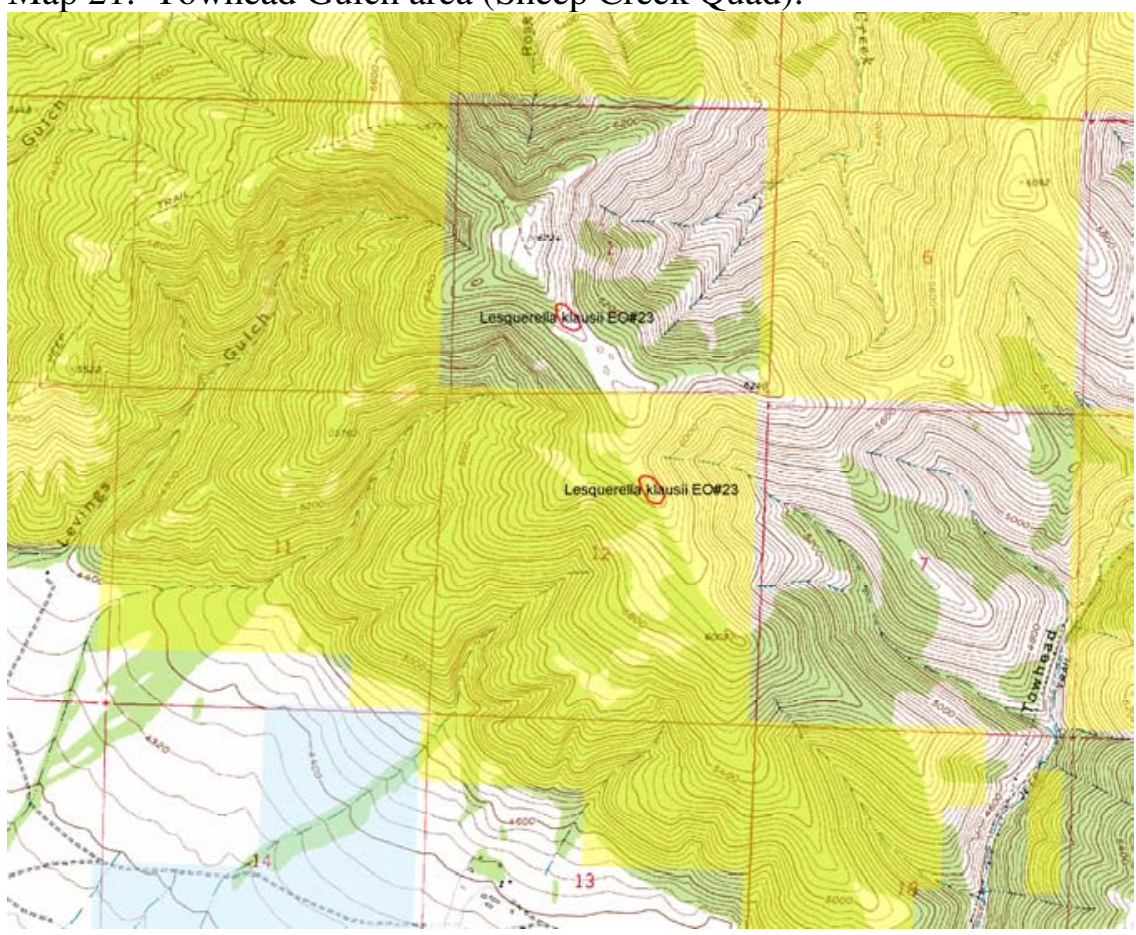

Map 22. Scratchgravel Hills (Austin and Scratchgravel Hills Quads).

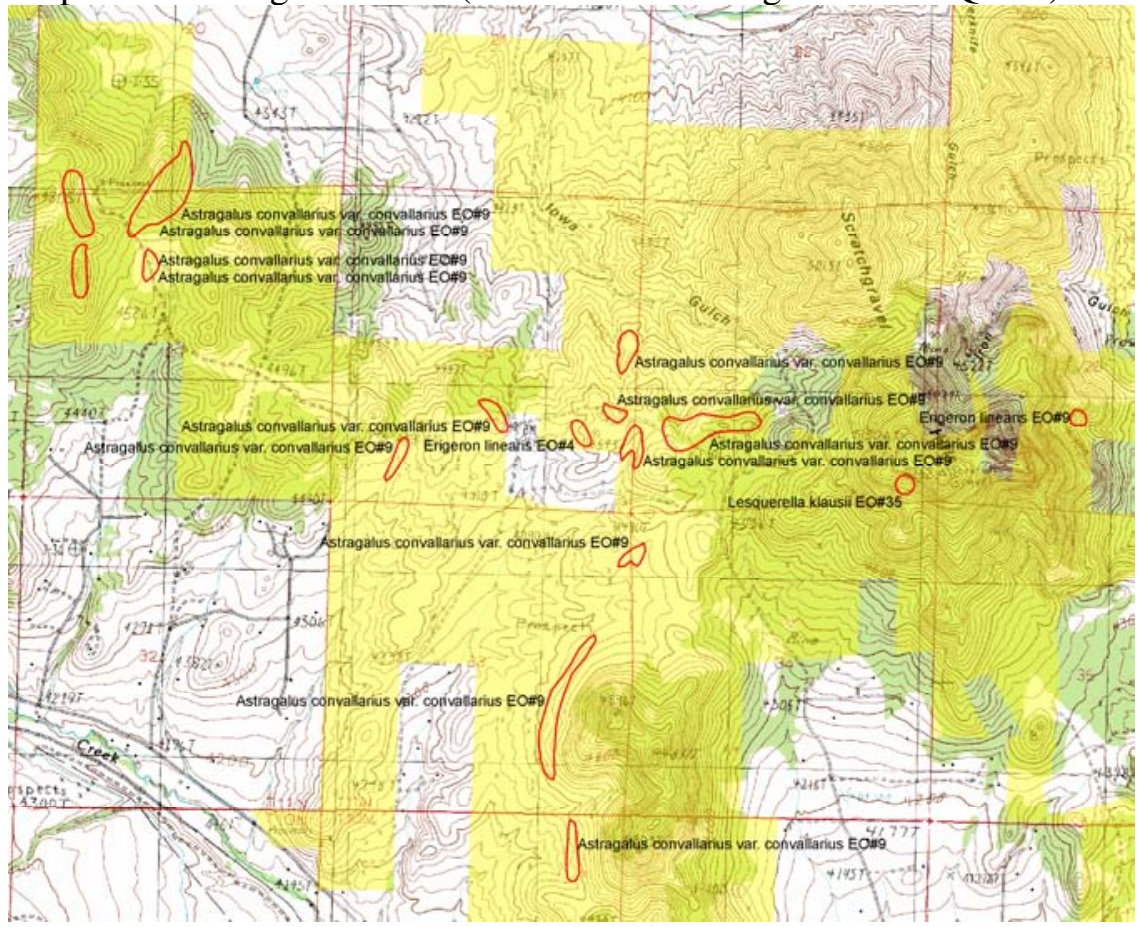


Map 23. Tenmile Creek area (Black Mountain and Helena Quads).

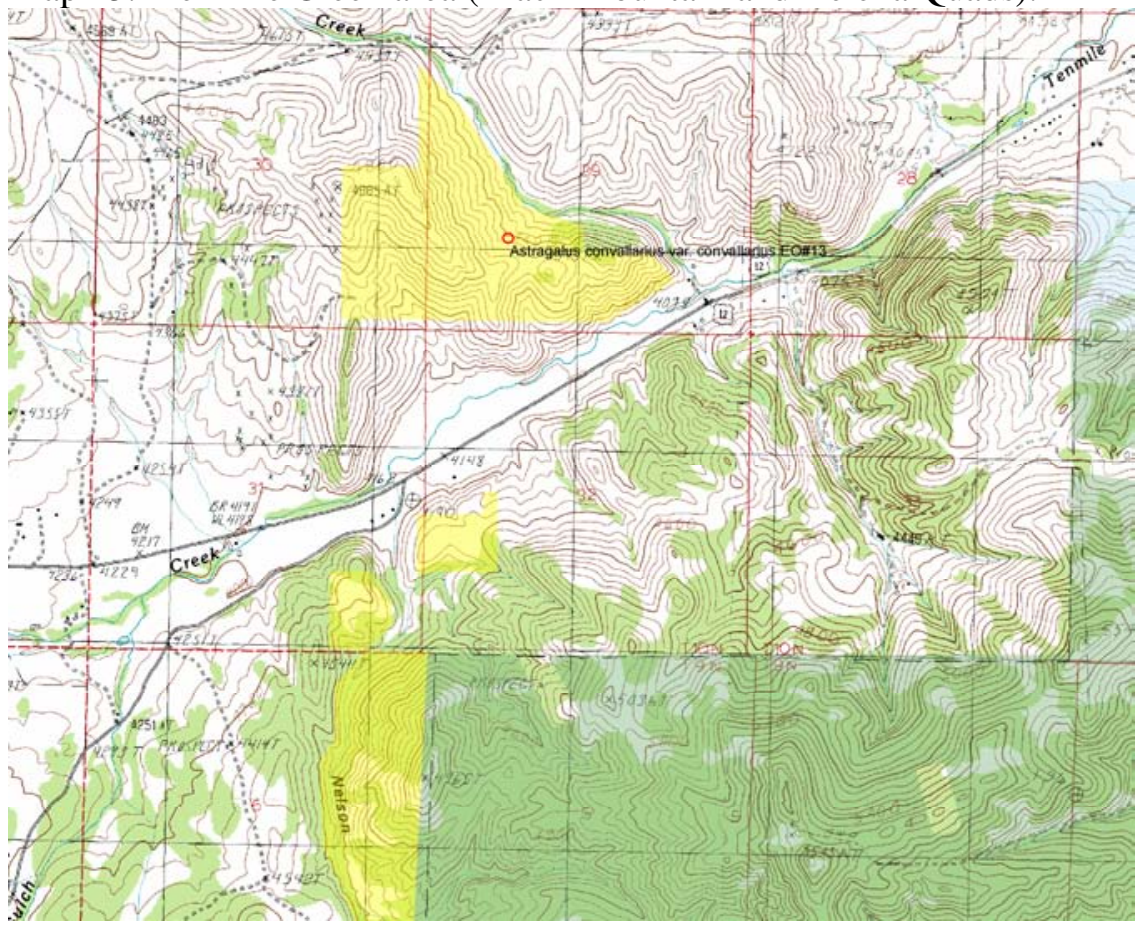

Map 24. Johnson Creek area (Wise River and Dickie Hills Quad).

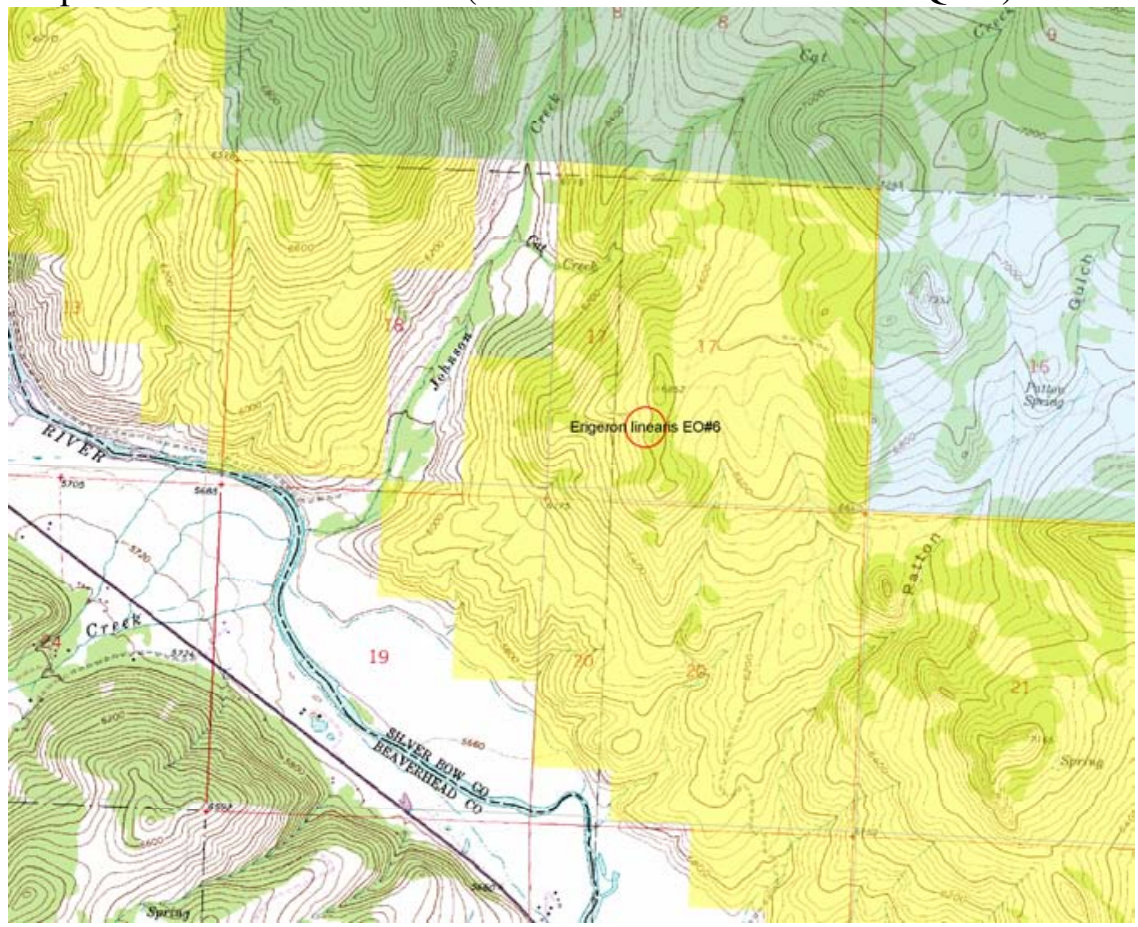

